Sue Brownill and Glen O'Hara

From Planning to Opportunism? Re-Examining the Creation of the London Docklands Development Corporation Planning Perspectives, $(30,4)$

This version is available: https://radar.brookes.ac.uk/radar/items/29bda23d-ecbb-43f2-a64e-d9832cbdc3ed/1/ Available on RADAR: 22.07.2016

Copyright (C) and Moral Rights are retained by the author(s) and/ or other copyright owners. A copy can be downloaded for personal non-commercial research or study, without prior permission or charge. This item cannot be reproduced or quoted extensively from without first obtaining permission in writing from the copyright holder(s). The content must not be changed in any way or sold commercially in any format or medium without the formal permission of the copyright holders. 


\title{
From Planning to Opportunism? Re-Examining the Creation of the London Docklands Development Corporation
}

\author{
Sue Brownill, Oxford Brookes University \\ Glen O'Hara, Oxford Brookes University
}

\begin{abstract}
East London's former docklands have been at the centre of planning and regeneration debates for the past four decades. The setting up of the LDDC has been variously interpreted as '3-D Thatcherism' in action, a symbol of the death of comprehensive planning and the replacement of a corporatist, Keynesian era of urban policy with a more neo-liberal approach. Moving away from simplistic and straightforward interpretations of the processes happening at this time, this paper uses new archival and interview material to re-examine the setting up of the LDDC and its early years, revealing a more complex and contradictory picture than existing accounts suggest. It focuses on three themes: changing forms of state intervention; the uncertain 'break' in the post-war consensus as evidenced by the changes in approaches to the regeneration of Docklands; and the unintended, disordered process of actual policy change. As such we aim to reveal how shifting visions, modes of governance and practices can compete and co-exist in the midst of seemingly coherent 'eras', as Docklands as a place and as an approach to regeneration was constantly made and re-made - a process that continues to this day.
\end{abstract}

\section{Introduction: Planning the Future of the Docklands Area}

The history of the London docklands' redevelopment is a broadly familiar one of industrial decline and the varied responses that this has elicited. ${ }^{1}$ The upstream docks began to close in 1967 as larger ships and containerisation led to trade moving gradually down-river to Tilbury: over a three year period the East India, St Katherine and London docks closed, followed by the Millwall and West India Docks in 1980 and the Royal Docks further downstream in 1981 (See Map 1). ${ }^{2}$ A succession of visions and projects were then put forward for how the resultant redundant spaces could be redeveloped. ${ }^{3}$ As Peter Walker, Conservative Secretary of State for the Environment, said in 1972 at the launch of a major Docklands regeneration study: 'all the ingredients are here for something big to happen' (see Table 1 for a summary of political control of the relevant authorities). ${ }^{4}$ However, what that 'something' should be and how it was to be achieved was hotly contested, with alternative visions and strategies being put forward by a range of interests: as we shall demonstrate, there was nothing inevitable about that 'something big' equating to the towers of Canary Wharf.

In 1971 central government made its first response to the decline of the enclosed docks and for the first time designated an area on a map called London Docklands when Walker announced his intention to set up the Docklands Study Team. Central government wanted to co-ordinate the piecemeal redevelopment already occurring, such as that at St Katherine Docks which had been sold to the Greater London Council (GLC), and to enable central government to control the large budgets necessary. But the proposals put forward in this first study, to establish a New Town-type organisation taking control from Local Authorities, was met by a storm of protest from the Labourrun borough councils and local communities. Partly as a result the Docklands Joint Committee (DJC), 
made up of representatives from the Boroughs, GLC, industry, community groups and key agencies such as the Port of London Authority (PLA) was set up in 1974, the same year a Labour Government was elected. In 1976 the DJC produced a non-statutory plan, the London Docklands Strategic Plan (LDSP), which set out to 'redress the deficiencies' of East London by focusing on reviving industrial employment and providing housing for the local population. ${ }^{5}$

\section{[Insert Map 1]}

Map 1. The London Docklands area and its environs.

However, by the mid-1970s the PLA found itself in accelerating financial trouble, and this made the need for some form of radical action even more acute. The Ministry of Transport estimated that the PLA would need a cash injection of between $£ 40 \mathrm{~m}$ and $£ 60 \mathrm{~m}$ to keep going until 1980 , and that if nothing was done about the docks' labour situation it would continue to need loans and subsidies thereafter. ${ }^{6}$ Furthermore, by 1979 and at the time of the first Thatcher administration's election, the Strategic Plan was falling behind its targets, leading new Secretary of State for the Environment Michael Heseltine to claim that to meet this challenge 'there is a need for a single-minded determination not possible for local authorities concerned with their much broader responsibilities'. His proposal was to create Urban Development Corporations (UDCs) 'modelled on the New Town Development Corporations and... given powers of planning, land assembly and disposal for private sector development and a range of other activities'. The London Docklands Development Corporation (LDDC) was therefore established in 1982 with a remit to regenerate Docklands through attracting the private sector to address perceived failures in housing and land markets in the area. This was not, of course, the end of the story, although it is the time-period on which this article focuses. The LDDC itself until its demise in 1998 went through significant changes from being market-driven to embracing 'social regeneration' from the late 1980s onwards while post-1998 successor bodies including Local Authorities, the Greater London Authority (GLA) and other regeneration agencies have arguably continued the 'strategic flexibility' practiced by the LDDC in their efforts to secure further private sector investment. ${ }^{8}$

[Insert Table 1]

Caption: Table 1. Political control of relevant authorities in London Docklands, 1970s-2000s.

One way of depicting this history is through a succession of different stages or planning 'eras' running from an apparent consensus in the 1970s, and centring on public sector-led approaches, through to the fracturing of such widespread agreement by the free market ideology of the early Thatcher years, to the re-establishment from the late 1980s of a new form of consensus built on public-private partnerships and planning gain. ${ }^{9}$ While useful (and see Table 2 for a summary of these different approaches) defining such eras can be problematical. Firstly, it can over-simplify the factors in play. Carmona for example employs only two criteria to define his eras: the shifting balance between plan- or opportunity-based, and between state- or market-controlled, approaches. ${ }^{10}$ It can, secondly, suggest that such eras are monolithic, represented by only one approach which is then superseded by another and that the progression from one to another proceeds in linear fashion. ${ }^{11}$ Thirdly, it can ignore the role of ideology and history in the ex post facto ascription of new justifications and explanations to the past. ${ }^{12}$ 
[Insert Table 2]

Caption: Table 2. A short history of London Docklands development.

There is a related tendency in such schematics to depict the Docklands as it emerged under the LDDC as an ideal type of 'three-D Thatcherism' and the physical legacy of her politics: a view underlined repeatedly in commentaries after her death in 2013. As one author has put it, 'where a maze of derelict warehouses and old cranes once testified to Britain's decline, glass skyscrapers teeming with traders now dominate London's docks, a metaphor - for good and ill - for Margaret Thatcher's free-market revolution' ${ }^{13}$ In addition, the LDDC itself, through a series of monographs and a legacy website, has attempted to reinterpret the past into a narrative of success. ${ }^{14}$ It is therefore timely to work towards a more nuanced understanding of the evolution of the planning of Docklands and to look again at the crucial period between the mid-1970s and mid-1980s when the coming together of actually much more complex transformations in industrial policy, planning and political ideology transformed Docklands. In our attempt to do so, we draw on work addressing policy 'assemblage', placing the emphasis on how different ideological and administrative elements were brought together, or assembled, in a contingent and uneasy way. This involves what Eugene McCann and Kevin Ward have termed the 'composite and relational character of policies and cities... [involving] various social practices that gather, or draw together, diverse elements of the world into relatively stable and coherent "things" [that are]... unexpected and nonlinear'. ${ }^{15}$

Such work includes study of the intellectual, temporal and spatial contradictions, contestations and tensions that exist within such assemblages and thus moves away from any sense of monolithic 'eras'. Our emphasis on overlapping chronological phases, revealing both complexity and specificity, might be thought of as a temporal counterpoint to those spatial approaches that, even at the time, rejected any simple set of causes or indicators as either causing or demonstrating Docklands redevelopment. Darrel Crilley's late 1980s attack on John Short's use of class as the key element in Docklands' transformation is a case in point: our argument similarly problematizes the idea of "ideology" or "politics" as a privileged or sufficient explanator of urban regeneration on its own. ${ }^{16}$ This article instead focuses on the work (or practices of assemblage) of policymakers and others in bringing and holding together the sheer volume of intellectual and practical elements that this labour entailed. ${ }^{17}$ It is a task that has been assisted by the availability of new documentary sources consisting of material released under the 30 year rule in the National Archives and previously restricted material from the LDDC now in the London Metropolitan Archives, as well as autobiographies and other reflections from key actors at the time. In addition fieldwork in the form of interviews with key actors and a workshop bringing together a range of those active at the time has also been undertaken. ${ }^{18}$

\section{Docklands Planning Prior to the LDDC}

As outlined in the introduction, two major regeneration efforts preceded the creation of the LDDC, differing in respect of key policy areas and the proposed governance arrangements. The Docklands Study Team, consisting of high-ranking officers from central government, the GLC and the five Docklands boroughs (Greenwich, Lewisham, Newham, Southwark and Tower Hamlets), reported in 1973 and produced 18 different scenarios that might exist in or about 1990, with between 25,000 and 45,000 new industrial jobs in the area, as well as between 12,000 and 50,000 new office jobs 
and including such flights of fancy as a safari park in the Victoria Dock. ${ }^{19}$ They gave their five preferred alternatives five evocative names: 'Waterside'; 'Thames Park'; 'East End Consolidated'; 'Europa'; and 'City New Town'. However the essential choice was between two: City New Town and East End Consolidated, with the latter 'subtly presented as an unattractive alternative' depending as it did on public housing and industrial employment (see Figure 1 and Figure 2). ${ }^{20}$ The favoured option, City New Town, involved 60,000 new service sector jobs and only 1,000 new industrial jobs. A population of 142,000 was envisioned, improving the 'social balance' in Docklands with a 50/50 public and private housing split plus an East-West spinal public transport route and associated shopping, services and open space. Ostensibly chosen via the application of 'rational' planning criteria based on identified problems such as housing, employment and transport, even the study team admitted they placed at least equal weight on the views of their clients, the Conservative-led $\mathrm{GLC}^{21}$

[Insert Figure 1]

[Insert Figure 2]

Caption: Figures 1 and 2. 'East End Consolidated' and 'City New Town' plans for London Docklands, 1973.

Source: London Docklands Study Team, Docklands: Redevelopment Proposals. The authors are grateful for the permission of Bromley Borough Council (as the GLC's successor body for copyright) and the London Metropolitan Archives to reproduce these images.

These plans were opposed by a number of local groups, who proselytized vociferously and effectively in favour of their own vision for Docklands. Coalitions of activists opposed the idea of a New Town in Docklands when giving evidence to House of Commons inquiries into the matter. ${ }^{22}$ The Joint Docklands Action Group became the umbrella grouping which represented their views to government, opposing the 1973 plans since 'it believed they would not significantly benefit the existing residents and workers of East London'. They called instead, for instance before the House of Commons Expenditure Committee in 1979, for industrial re-location to Docklands, and the construction of affordable housing developments that would re-house existing, rather than incoming, residents. ${ }^{23}$ Planners and officialdom alike harboured doubts about their apparent spontaneity. David Eversley, who had himself worked as one of the GLC's Chief Planners, dismissed such groups as led by figures 'from outside the community... using local residents as "front men" for their activities', often with 'principal link[s] to various left wing organisations', 'other young people mainly of upper middle class origin who... often had little knowledge of what was involved', circulating propaganda written in 'virtually unintelligible sociological jargon', ${ }^{24}$ a view shared by some local residents. ${ }^{25}$

The Heath Government of 1970-74 had been strongly interested in the idea of a 'special agency', initially to be set up under, and be responsible to, the GLC - controlled at this point by the Conservatives. But the idea proved impossible to sell to the five local authorities involved, all of which were governed by the Labour Party. Geoffrey Rippon, himself a member of the London County Council in the 1950s and now Secretary of State for the Environment, did consider legislating to set up a Development Corporation, along modified New Town lines. He prepared to publish a White Paper proposing just this in the summer of $1973 .{ }^{26}$ The boroughs, instead, 'very strongly urge[d] on 
Ministers' the concept of a statutory joint committee of all the councils involved - which led to the setting up of the DJC, its sixteen members drawn equally from the GLC and the boroughs. ${ }^{27} \mathrm{~A}$ new Labour administration at County Hall furthermore announced that it was scrapping the consultants' study, which it condemned as a 'series of dreams'. Instead, the GLC placed a renewed emphasis on 'council housing, industrial employment and, if possible, keeping docks... working' .The DJC was granted powers of strategic planning and development control by the boroughs, but its main task was to draw up a non-statutory strategic plan for the area fitting between the GLDP and the borough's own plans. ${ }^{28}$

So the first attempt to 'assemble' Docklands along a particular trajectory was replaced by a second attempt that focused on inter-borough regeneration from the bottom up during a renewed period of Labour government at Westminster. In 1976 the Docklands Joint Committee published the London Docklands Strategic Plan, the explicit aims of which were 'to redress the housing, social, environmental, employment, economic and communications deficiencies of the Docklands areas the parent Boroughs'. ${ }^{29}$ Economic policies were not based on the service sector but on the stabilisation of industrial employment and the attraction of new industry: the docks still operational in 1976 were assumed to remain so for the life of the plan. 23,000 new houses were envisaged with a mix of $50 \%$ publicly rented, $30 \%$ shared ownership (including housing associations) and $20 \%$ owner-occupied. These were to be built in neighbourhoods surrounding individual centres spaced along the riverside. New transport in the form of an East-West Underground link, roads and river crossings would allow the development of a 'grid' of north-south, as well as east-west, industrial and commuting links across the area (see Figure 3 and Figure 4$).^{30}$

[Insert Figure 3]

Source: Docklands Development Team, Housing.

[Insert Figure 4]

Caption: Figures 3 and 4. Docklands Joint Committee plans for the area, 1976.

Source: Docklands Development Team, Transport. The authors are grateful for the permission of Bromley Borough Council (as the GLC's successor body for copyright) and the London Metropolitan Archives to reproduce these images.

However, bringing and holding together all the elements of the policy assemblage needed to deliver this vision proved difficult. In terms of physical space, the GLC and the boroughs initially continued to acquire land from the PLA with the London and Surrey Docks being bought and filled. The DJC expected that the Community Land Act of 1976 - which allowed councils to buy up land at prices based on current, rather than hoped-for, uses, and exempted local authorities from paying tax on land they acquired - would enable them to assemble the large areas of derelict land earmarked for development. ${ }^{31}$ A Docklands Land Board (DLB) was established in 1977 to buy up land in this way, and the Department of the Environment (DoE) indicated that it was willing to allow loan sanctions for the purchase of 224 acres for subsequent development. The DLB thought it might then be able to initiate development on a similar basis to the post-war New Towns. But the Act proved an inadequate tool, and by the time of its dissolution in 1980 the Board had only acquired 3.3 acres. These administrative arrangements were, furthermore, only bureaucratic elements intended to 
deliver a set of plans that were supposed to be constructed from the bottom up, as well as the top down. The DJC intended that local residents should be involved in the planning process through local Action Groups, and a 'Docklands Forum' 'representing a wide cross-section of interests'. There was an Action Group for each constituent area of the area under study by the DJC, meaning that there were six in total (for Lewisham, the Isle of Dogs, the Surrey Docks, the Mile End/ East End Docks area, Newham and Greenwich). ${ }^{32}$ The Forum did not, however, always work as well as the DJC's proponents hoped it might, for it was a relatively large body, operating across a very wide and disparate area. It also became more bureaucratic as time wore on, appointing an Executive Committee and reorganising its officer structure on a more complicated basis during 1978 . One chairman of the Docklands Forum indeed thought that his group 'made no significant impact on either general policies or on particular decisions' ${ }^{33}$

The achievement of the DJC's aims was therefore highly constrained. While the DJC had pressed ahead with a programme of practical work, such as dock filling, and hoped to build projects that had already been given planning approval, a 1978 review showed that targets were not being met. As public finances were not forthcoming there was greater reliance on the private sector. The inclusion of schemes such as a 'Trade Mart' in Surrey Docks which favoured service sector employment and provided no housing is an example of how the aims of the Strategic Plan were bypassed: as a result, it became a 'compromise between the interests of private developers and the local workforce and community in Docklands'. ${ }^{34}$ Such travails demonstrate that the changes in the trajectory of regeneration in Docklands were not solely attributable to top-level political change and that even within the social-democratic 'era' there were a variety of different approaches emerging in tension with each other: the original plans for a New Town-style redevelopment and an emphasis on service industries; a period of consultative local co-operation; and a later 1970s return to an increased emphasis on private sector initiative.

Potential responses to this were threefold. There were, first, attempts to refocus the inter-authority approach even further on profit-seeking activities. The five borough authorities involved appointed Industrial Liaison Officers to assist with employment and investment work, and the GLC reorientated some of the efforts being made by its own Industrial Centre eastwards. ${ }^{35} \mathrm{~A}$ Docklands Development Organisation (DDO) was set up, aimed at attracting more private sector development. One of the first responses of the DDO was to revise the LDSP population targets down, call for more commercial development and increase the target for private investment to $70 \%$. Under the 1978 Inner Urban Areas Act (IUAA), Docklands became a partnership area with a Partnership Board alongside the DJC. As Brownill has previously stated, though discourses of 'partnership' imagined cooperation between local authorities, the private sector and local communities - a quite different emphasis from later Thatcherite cadences - such concepts could still 'be seen as the first move towards the centralised and private sector regime in Docklands', as the emphasis was on bringing in private finance and funds for housing and land purchase were not available through the IUAA. ${ }^{36}$ In contrast an alternative strategy was being put forward by local organisations and trades unions, as well as some local politicians, calling for much greater central government investment utilising Labour's new National Enterprise Board and concerting the disposal of public land. These alternatives were to culminate in the policies of the GLC from 1981 onwards which stood in such direct opposition to the LDDC. The 1981 election manifesto for a 'socialist policy for the GLC' contained five pages on Docklands and included calling for the principles of the LDSP to be upheld, 
as well as pledging GLC support for 'opposition to the UDC' ${ }^{37}$ The third alternative, to which we now turn, was to create new and equally radical, but market-orientated, solutions.

\section{The Creation of the LDDC}

The Thatcher Government moved very rapidly to establish its new Inner City policy. The new Secretary of State for the Environment, Michael Heseltine, put a paper to the Economic Affairs SubCommittee of the Cabinet in July 1979 outlining proposals for UDCs in London and Liverpool. Keith Joseph, in a minute to Thatcher, noted that this 'radically new approach' for a 'single-minded development agency' received a 'rapturous reception' but added it would no doubt have implications for public expenditure and urban and regional policy. ${ }^{38}$ Heseltine was keen to make an announcement in early September: an inter-departmental working party was set up to make recommendations on a wide range of aspects including housing, consultation, industrial policy and planning powers. This had done sufficient work for Cabinet discussions to be concluded and for Heseltine to make a statement on 14 September to the Royal Town Planning Institute Summer School in York. In this speech he announced the setting up of UDCs on Merseyside and in London. A chairman - Nigel Broackes from the property investment conglomerate Trafalgar House - was then approached for the LDDC, and his appointment settled by the end of the year. ${ }^{39}$ This was followed by a consultation document issued by the DoE and the creation of UDC powers in Part XVI in a new Local Government, Planning and Land Act, passed in $1980 .{ }^{40}$ The designation of the areas to be included and the setting up of the Corporations were set out in orders laid before both Houses of Parliament in November 1980.

Neither were UDCs the only policy initiative from the Government. The Chancellor, Geoffrey Howe, had also put forward ideas for Enterprise Zones (EZs), smaller areas in which the 'red tape' of planning and tax burdens would be lifted from enterprise in order to promote private sector investment. The package was eventually settled in Cabinet Committee by the end of February 1980: after some wrangling, EZs eventually involved the granting of 100 per cent capital allowances for commercial buildings and total rating remission for ten years, as well as the waiving of the normal procedures for acquiring planning permission. ${ }^{41}$ While not included in the initial UDC proposals, the designation of the Isle of Dogs EZ in 1982 became a crucial factor in the redevelopment of the area.

UDCs were to be given extensive powers of land assembly and disposal, to take over planning control powers from the Local authorities, and to be accountable to a Board appointed by the Secretary of State, not the local electorate. Nevertheless the 1980 Act contained sections lifted verbatim from New Towns legislation, and in subsequent interviews LDDC officers have confirmed the influence of the New Towns as a 'model' over what they were trying to achieve in Docklands. ${ }^{42}$ The difference was that in this assemblage, development corporations were placed within a very different ideological context. Thornley has distinguished three main features of New-Right planning at this time. ${ }^{43}$ Firstly, the neo-liberal domination of decision-making by individual and market criteria over collective social or community concerns. Secondly, what he terms 'authoritarian decentralism' through which the centre appropriates power and then decentralises it, in the case of UDCs through the appointment of a board of predominantly private sector interests accountable to the secretary of state. Thirdly, there is what Thornley sees as the anti-bureaucratic element and the replacement of 'red tape' with flexible planning procedures backed by law which allow the private sector room 
for manoeuvre. Other authors have stressed a fourth element, which is the desire to reduce public expenditure and to rely on more private investment and provision. ${ }^{44}$

But while some of these elements were undeniably present within the UDC proposals, there were others in play, increasingly brought into the open during Heseltine's attempt to steer his proposals through Cabinet. First and foremost there was a clash between some of these concepts, especially between authoritarian decentralisation, the Thatcher government's overriding aim of public expenditure constraint and the role of markets. ${ }^{45}$ Contemporary documents reveal that Joseph's Department of Industry was concerned at the implications for regional policy should development in the relatively successful economy of London be in effect promoted and subsidised by government, as well as the movement of responsibility to the DoE. ${ }^{46}$ Estimating expenditure was difficult due to the fact there were no proposals as yet from the putative LDDCs, and projections varied from $f 30 \mathrm{~m}$ $f 85 \mathrm{~m}$ per year. A working paper setting out a variety of options for Docklands, including keeping the DJC and a UDC, spelt out that the UDC was only viable with increased input from the Exchequer and the lowest cost options were to keep the DJC or put the Boroughs in control. ${ }^{47}$ But the extent of central government intervention in local economic affairs also posed an intellectual challenge to the first Thatcher administration. The Treasury under Howe was also concerned at the implications for public spending, as well as possible 'contradictions' with its own EZ initiative. Arguably EZs can be seen as 'purer' form of free-market initiative avoiding the setting up of an agency, which although market-friendly, was still part of the state. ${ }^{48}$

The resolution of this conflict can be explained via a vignette from Heseltine's memoirs, where he recounts a meeting between himself, Howe, Joseph and Thatcher at which objections to UDCs from his fellow ministers were over-ruled by Thatcher in response to Heseltine's assertion (fed to him by Reg Prentice, the former Labour MP for East Ham who had defected to the Conservatives) that the Docklands local authorities were 'all run by communists' ${ }^{49}$ As Heseltine commented: 'I had lit the blue touch paper. The rocket went off', with the result that Thatcher's political priorities about the 'enemy within' and the exclusion of local, particularly Labour, authorities from decision-making overrode concerns over public expenditure and new powers for central government. However, the stress placed on 'present arrangements' in the September statement was insisted on by Cabinet members as an attempt to control resources and contain UDC activity to within existing limits. ${ }^{50}$ Further, the Treasury made it clear that there would be no more money for Heseltine's department and anything above what would have gone to the DJC would have to be taken from other parts of the DoE's spending. ${ }^{51}$ From the start tensions were embedded in this assemblage between different strands of urban policy contained within the LDDC approach. As Cochrane has noted, and as evidenced by the responses of Joseph and Howe, UDCs 'were not the pure children of Thatcher because they drew on a clear cut interventionist agenda'. ${ }^{52}$

The contradictions in the scope of state activity in this new policy assemblage were added to by ones of scale. The practice of 'authoritarian decentralism', removing local power to place it in the hands of the central state and the private sector, brought with it its own tensions. Most obvious amongst these were in relations with the local authorities and the GLC: however, despite being created by central government, one of the major features of the LDDC was its fractious relationship with its parent. As an illustration of these tensions, examination of archives from the time reveals that there was much discussion by civil servants on the extent of powers, responsibilities and spending 
authority to be given to UDCs. Many within Whitehall imagined the creation of a more traditionallyminded authority than they initially unleashed: some senior civil servants asked to draw up the proposals thought the DJC 'not so manifest a failure' as to warrant an alternative, as well as once again highlighting the cost implications. In one telling memorandum the consensual DJC was preferred, 'for the alternative is a red-blooded, meat-eating tiger' that would attack the 'sacred cows of planning, consultation and fair process' - in many ways the politicians' intention. Nevertheless, presciently, the author commented that the reaction to this would mean the tiger would inevitably be watered down to a 'domesticated she-cat' in time. ${ }^{53}$

Civil servants' caution about future negotiations was entirely warranted. Docklands' borough councils were opposed to the entire concept of a Development Corporation, especially since they felt that they had themselves already cleared away many of the structural difficulties of redevelopment - drainage, site clearance and the like. They always made clear that they would wait until the Royal Assent was granted fully to co-operate with the new Development Corporation. Heseltine accepted that they 'were feeling aggrieved that the decision had been taken to set up a UDC in Docklands... without prior consultation', but in October 1979 impressed on GLC, Lewisham, Newham, Southwark, Tower Hamlets and Greenwich leaders that 'the area... required a centralised body with flair, single-mindedness, dynamism and above all concentrated power to act'. ${ }^{54}$ Still, as the same local authority leaders told Heseltine in February 1980: 'the UDC concept was not one which Docklands Leaders accepted readily... Docklands Local Authorities were firmly against the UDC proposals and there was going to have to be considerable understanding over the coming months if progress were to be made'. ${ }^{55}$ Greenwich's Chief Executive summed up the boroughs' proposed counter-offer: 'a forum for co-ordinating the Council/ local group/voluntary body interests... to disseminate information relating to urban aid and other financial assistance... to provide advice and assistance to local groups... to work up jointly proposals for utilising the financial assistance for the benefit of the residents'. The DJC would be retained, even if given new powers, under proposals the boroughs attempted to popularise with the title Local Democracy Works (Figure 5). ${ }^{56}$

\section{[Insert Figure 5]}

Caption: Figure 5. Cover of pamphlet arguing the case for keeping the DJC, showing council housing under construction in Wapping.

Source: Docklands Borough Councils, Local Democracy Works. The authors are grateful for the permission of Greenwich Borough Council to reproduce this image.

The response to these political differences was to appoint Bob Mellish, Labour MP for the Bermondsey area of Southwark and a previous Cabinet minister, as shadow vice-chair of the UDC. The leaders of the three Docklands authorities were also offered board membership as individuals, not as representatives, and had to abide by the regulations of the board in that meetings were secret with no published minutes or agendas. However, if this was an attempt to construct a policy assemblage which would work it failed. Conflict with the boroughs remained and as local politics in some parts of Docklands moved towards the left, Mellish was deselected as an MP for the 1981 election and the new Leader of Southwark resigned from the Board: the borough then refused to have any contact with the LDDC for a number of years. ${ }^{57}$ 
Some Whitehall officials had, even so, by now convinced themselves that they had taken the right course of action - though for rather more dirigiste reasons than Ministers. As they further concluded after their success in convincing the House of Lords Select Committee of the case for a UDC:

Some of the objectives of the LDSP were wrong anyway. The DJC were trying to reinforce the composition of the existing community which was based on the docks and associated work. It was not trying to create the conditions for growth by way of new or expanding industries. In any case, if it was a national problem then it required national money to solve it. In that case, the Government was perfectly entitled to have a say... The Boroughs insisted that it was a purely local difficulty but nevertheless wanted the Government to come up with the money to deal with it. They couldn't have it both ways. ${ }^{58}$

Similar views were stated at the relevant House of Lords Inquiry. It was claimed that that the Docklands boroughs were 'parochial', that they could not agree and the DJC did not have the powers to deliver. Instead what was needed was a 'single-minded authority' which could develop Docklands in the 'national interest' and bring in the 'funds and energies of the private sector'. ${ }^{59}$ Their Lordships agreed and made only two caveats in relation to the provision of land for public housing and consultation with the boroughs and the Docklands Forum. And so the LDDC was established in July 1981, assuming its planning powers two months later. This did not, however, end the debates over public expenditure, direction and control - in which some Ministers were deeply concerned about the spending and legislative implications of Heseltine's reforming urban agenda, and many officials advocated the creation of a new Corporation partly because of exasperation of the boroughs' inaction. There were therefore contradictions of both scale and scope within the newly formed UDC policy assemblage.

\section{Rolling Back the State?}

These tensions between Whitehall and the LDDC were deep-seated, and continued for much of the 1980s - partly because the LDDC's first Corporate Plan and its mapping was so vague and unenlightening as to its borders and contours. Reg Ward had been appointed as Shadow Chief Executive prior to the House of Lords decision and complained bitterly in March and April 1981 that the UDC was not being allowed to operate in its own right: that a 'conceptual gap' had opened up between the extensive independence the LDDC had been promised, and the 'double-checking', bureaucratic and ultimately directing role of the DoE. Asked to prepare the first Corporate Plan, which set out the aims and objectives of the LDDC and also set out the budget and bid for government resources, Ward found most maddening civil servants' 'circular' arguments, insisting that the business plan had to be coherent when it came to the rapid collection of enough land for development overall, while insisting that each individual project should be tested for its contribution to the Corporation's objectives. ${ }^{60} \mathrm{He}$ argued that it went against the purpose of a UDC to either set out detailed plans or to expect the UDC to go through the DoE's usual project appraisal processes and his submitted first document was literally a few scribbles on a map (see Figure 6).

\section{[Insert Figure 6]}

Caption: Figure 6. Reg Ward's first attempt at defining the area to be covered by the Docklands Development Corporation. 
Source: The National Archives, AN 81/215. This material is Crown Copyright and is reproduced with the permission of the Controller of Her Majesty's Stationery Office (HMSO) at The National Archives.

Civil servants' concern was not so much about the niceties of planning but the control over the spending of public money: New Towns had significant budgets but they also had definite responsibilities. Officials were very worried about the LDDC, minuting that 'the main problem... is the apparent inability of the shadow Corporation to organise itself, and to prepare programmes which can start to roll immediately... Mr Ward is unable or unwilling to weld together the machinery, and provide the thought out and detailed information needed, if the UDC is to function effectively'. ${ }^{61}$ This memorandum suggested Ward be removed as he was not up to the job, but such concerns could also be seen as a response to a perceived challenge to the DoE's role. Ultimately Heseltine came down in favour of his civil servants, arguing that as public money was involved he was accountable to Parliament - though he had already asked that the Treasury show some flexibility about the financing of initial land vesting, and his civil servants were eventually able to reach agreement on this basis. Even so, the reporting system was still thought by the LDDC to be causing 'unnecessary delay' later in 1981, prompting officials - and Heseltine himself - to offer a series of small improvements, such as grouping minor project approvals together on one form. ${ }^{62}$

It took three attempts to settle an acceptable Corporate Plan, and it was not approved until some months after the LDDC had been formally set up having ultimately been drafted with the support of further additions to the LDDC officer team. Ward stayed (for the time being, though he was pushed out in 1987), but the board and officer team was strengthened in an attempt to make good some of these deficiencies, including the appointment of Wyndham Thomas (General Manager of Peterborough New Town) as a board member. Interviews with ex-LDDC officers have confirmed this early tension between a new breed of 'swashbuckling', entrepreneurial civil servants intent on putting the ideology of free-market planning into practice and a more cautious central bureaucracy carried on for some years. ${ }^{63}$ Tellingly a video produced by the LDDC at the end of its life, entitled The Battle for Docklands, recounts not its battles with the local community but with central government.

\section{The LDDC and the Variants of 'Anti-Planning'}

The LDDC was possessed of a different vision to the imagined solutions of the 1970s: one that involved freedom from - not the necessity of - governmental action and involvement. As Broackes wrote in the first annual report: 'the era of the grand plan has passed' ${ }^{64}$ The demands of developers would replace needs-led planning based on providing for existing communities: 'planning without a master plan', in the words of the geographer John Hall. ${ }^{65}$ Replacing the entire concept of local authority leadership and consultation, the new LDDC would now become the local planning authority for the whole of its area... and for all kinds of development for which a borough is at present the local planning authority'. Flexible strategies to entice private development, as shown in the Local Development Framework for the Royal Docks (Figure 7), were to replace detailed land use plans. Indeed the local authorities were conceptualised as being part of the problem, with the 'socio-economic' plans of the Docklands authorities pushing away private pushing out the private sector. ${ }^{66}$ The statutory development plans which gave overall direction would remain within the purview of the GLC and the boroughs; but there was no room for doubt that this was a fundamental departure from previous practice. ${ }^{67}$ The boroughs, for instance Newham, were privately assured that 
'it should not be assumed that the UDC would want to intervene or displace the local authorities just for the sake of it. They would undoubtedly want to see things happen but they would not necessarily want to do everything themselves'. Even so, the LDDC was now indisputably the lead planning authority: Heseltine asked personally that shops, offices and industrial buildings be taken out of the GLC's purview, along with planning applications and appeals. ${ }^{68}$ And Newham's fears were realised in 1986 when its statutory plan for the Royal Docks area (the South Docklands Plan) was refused adoption on the grounds that it contradicted the LDDC's vision for the area. ${ }^{69}$

\section{[Insert Figure 7]}

Caption: Figure 7. The LDDC's 'flexible' approach to planning, encapsulated in the Local Development Framework for the Royal Docks.

Source: LDDC, Royal Docks Area Development Framework. The authors are grateful for the permission of the Housing and Land Directorate of the GLA to reproduce these images.

Heseltine stressed agency rather than ideology in his September 1979 statement, asserting that 'I do not think the present arrangements can meet the particular problems and opportunities' (emphasis added). ${ }^{70}$ But officials working for the shadow LDDC were freer to articulate other strands in the new thinking, particularly those of removing the 'red tape' of planning. It appears that from the outset Ward, as first Chief Executive of the LDDC, was keen to take the LDDC in just this direction. Thornley has cited an early presentation of Ward's made in 1981, in which he indicated the prime role of the LDDC would be the marketing of prime sites and that firms with finance would be given an almost free hand, at least until the next general election. ${ }^{71}$ However, it is clear that while UDCs came to be viewed as the 'flagship' of this new planning order there were competing and contradictory narratives which entered the assemblage and which were to become apparent in LDDC developments on the ground. It should also be remembered that the LDDC's was not the only vision for Docklands at the time. The boroughs and local campaigning groups maintained their commitment to the LDSP after the establishment of the LDDC. They were supported in this by the GLC who were keen to push forward their socialist alternatives to Thatcherite policies. These were made real in The People's Plan for the Royal Docks, which used bottom-up 'popular planning' to propose alternative uses to what was to become London City Airport based on social housing and retaining dock-usage to support a sustainable transport policy (Figures 8 , 9a and 9b). ${ }^{72}$

[Insert Figure 8]

[Insert Figure 9a]

[Insert Figure 9b]

Caption: Figures 8 and 9. The cover and land use maps of the The People's Plan for the Royal Docks, a localist and 'bottom-up' alternative to the LDDC's vision.

Source: Newham Dockland Forum, The People's Plan.

An example of how the LDDC's approach to planning asserted itself in the face of these possible alternatives is revealed through archival evidence of negotiations between the LDDC and PLA. At the setting up of the LDDC the PLA still had extensive landholdings but it was also in financial crisis and was negotiating a new five year Corporate Plan with Norman Fowler, the then Transport Secretary. ${ }^{73}$ 
In the recent past it had been a partner in the DJC both out of self-interest to generate income but also out of a particular idea of how a public agency should operate. The PLA's desire to be a landowner with a social conscience and a long-term stake in the area represented a clear alternative to the increasingly market oriented and 'doctrinal' LDDC. The development of other European port cities, for instance Hamburg and Rotterdam, can be seen as having carried through this alternative approach with arguably mixed results, but in a way which has been both more inclusive and strategic. $^{74}$

At a meeting between Broackes and PLA Chairman Victor Paige minuted by Broackes himself, the differences between the two agencies were clearly set out. ${ }^{75}$ PLA policy was to sell the freehold of land only for community purposes; for any other commercial uses it would participate in development retaining an equity stake. Paige stated that 'the PLA takes seriously its social conscience' and it wanted to be 'a land-owner not a property company'. In contrast the LDDC wanted land-use to move 'up-market' and would sell land on as quickly as it could. Minutes of further meetings between civil servants confirm the view that 'the job of the PLA was to run a port not act as a social landowner'. ${ }^{76}$ To resolve the issue Broackes called for a 'doctrinal statement by government' and that the matter' should be settled at Ministerial level'. ${ }^{77}$ This duly did occur, with Heseltine writing to Fowler that he was not prepared to accept anything other than the LDDC vesting the PLA's land and the suggestion that Paige should be appointed to the LDDC board member was rejected. ${ }^{78}$

This vignette also raises the issue of the role of particular actors in the practices of assemblage. The fluid situation during the setting up of the LDDC showed there were different possible trajectories on offer: social landowner; New Town Corporation; and 'meat-eating tiger'. Having a Chairman from a property company appeared to steer it in a particular direction. The LDDC policy was thus to sell on as much of the 173 acres (out of 482 acres) that it owned within the Development Area as quickly as possible to the private sector. ${ }^{79}$ Broackes was aware of the significance of land to the private sector and pushed hard to get as much land as possible vested in the LDDC. The PLA's desire to be a landowner with a social conscience and a long-term stake in the area represented a clear alternative to the increasingly market oriented and 'doctrinal' LDDC. Such incidents show not only how close such approaches came to rejection, but also highlight the role of particular actors in the indeterminate processes of policy-making.

Although space does not allow us to trace the continuation of these tensions in detail, it is important to note that even though they were never resolved despite attempts to do so leading to further policy changes. In some senses Howe and Joseph were right; the LDDC might have claimed that it was market-led, but it entailed the spending of around $f 6 \mathrm{bn}$ in public money when taking into account the enormous public investment in the Docklands Light Railway and the eventual arrival of the extended Jubilee Line, as well as the use of extensive planning and land acquisition powers. ${ }^{80}$ Such sums led to the 'reining-in' of the LDDC with the replacement of Ward as Chief Executive in 1987 , firstly by a previous local authority chief executive, and secondly an ex-DoE mandarin; the 'meat-eating tiger' had indeed become a 'domesticated she-cat'. Neither did conflict with the boroughs, GLC and community dissipate. Indeed as the results of LDDC's initial strategy epitomised by Canary Wharf materialised, with seemingly little to benefit local residents, concerns about its appropriateness began to be expressed within central government and led to the Corporation's 
'second wave' which incorporated social investment, such as at the Britannia Urban Village in the Royal Docks (Figure 10). ${ }^{81}$ Further the perceived deficiencies in de-regulated planning, such as the lack of co-ordination between land-use and planning seen at Canary Wharf which necessitated the massive infra-structure investment led to the adoption of what Florio and Brownill have termed 'strategic flexibility'..$^{22}$ This was not a return to a plan-led approach but sought to balance enabling private investment with wider considerations and signified a re-emergence of the significance of partnership in regeneration: issues which often arose out of the LDDC's housing activities, to which we now turn.

[Insert Figure 10]

Caption: Figure 10. Britannia Urban Village, a mixed-tenure development built during the LDDC's 'second wave'.

Source: author photograph.

\section{Docklands Housing}

Housing was at the nub of what civil servants and planners thought was 'wrong' with Docklands in the 1970s, and we concentrate here on the housing stock as a way of focusing attention on the different solutions on offer at the time. There were two aspects to this. Firstly, as the DJC consultative document of 1975 noted, this was one of the worst areas of housing dilapidation surveyed in the Ministry of Housing's 1967 Surveys; local residents put 'build housing' right at the top of their answers to 'what needs doing in Docklands?" ${ }^{83}$ The 1976 DJC plan noted that 40 per cent of Docklands residents had thought of leaving the area because of its housing problems. ${ }^{84}$ The central Action Group on London Housing, which drew in officials from across Whitehall, told the Joint Committee in October 1975 that 'adequate provision should be made for housing' in the Plan. 'All speed should be shown in getting land into housing use', they continued: 'of all amenities it is good housing which most is at a premium in London... [so] the share of land to be dedicated to housing should be the greatest which sound planning would allow'. The docklands boroughs had severe housing problems across the rest of their purview: Tower Hamlets considered housing stress in Spitalfields to be far worse than that in, for instance, Wapping. They were therefore more than keen to proceed as quickly as possible, in order to move tenants back into new or reconditioned housing in docklands - all an urgency that docklands MPs pressed on Rippon when they met with him in April 1973. ${ }^{85}$ The London Docklands Study of 1973 assumed that progress would 'overcome deficiencies in the housing programmes of the 5 London Boroughs after the first 2 or 3 years of redevelopment... indirectly eas[ing] the housing problem in the rest of Greater London' ${ }^{86}$

The second issue was the tenure mix and by implication the socio-economic 'balance' of the population. Due to wholesale post-war reconstruction the vast majority (up to $95 \%$ in some areas) of Docklands' housing was local authority owned. For some planners, this presented a problem not only of a mono-class area but also in terms of there being no opportunity for residents to achieve their 'aspirations' for home ownership and in terms of attracting higher income and higher skill workers as part of the developing the economy. ${ }^{87}$ As civil servants noted, there was a perceived 'need to provide for local white collar employees who want to be owner occupiers'. This would 
involve a large change in tenure type, but 'without such a reversal, there will not be balanced communities', as one private minute put in during $1976 .{ }^{88}$

The Docklands Strategy that the DJC decided on during 1975 and 1976 envisaged housing a Docklands population of 110,000 with some upward movement in that figure given density rule changes later in the decade. ${ }^{89}$ The tenure balance was set, depending on the area, at $40-50 \%$ owned by local authorities, $30-40 \%$ 'mid-tenure' (involving types of shared ownership), and $20 \%$ owneroccupied. The plan recognised that mass private housing was not the solution: 'to introduce private housing into East London on these terms would do little for the vast majority in need of housing', it argued. Instead, untried but innovative forms of equity sharing, housing associations and tenants' co-operatives were suggested which would also be allocated by the local authorities according to need. ${ }^{90}$ The DJC also hoped that the GLC would sell some of the dwellings it built onto the open market, so as to 'go some way towards redressing the imbalance between tenures' ${ }^{91}$ However, Whitehall planning officials did not envisage a vast role for co-operatives or Housing Associations, feeling that these might only 'play a useful part in catering for special groups, e.g. young single workers, students etc.' Instead the Plan recommended experimentation with 'equity sharing' schemes between local authorities and groups of individuals, in order to reach the target of 23,400 new dwellings in Docklands by the 1990s. Just under half of the total new dwellings would, however, still be built and owned by local authorities. ${ }^{92}$

\section{[Insert Figure 11]}

Caption: Figure 11. Luxury flats such as Pan Peninsula proliferated in London's Docklands during the LDDC period.

Source: author photograph.

The LDDC's approach to housing was very different - the reason why high-rise, high value, gated residential communities such as Pan Peninsula are now so common in Docklands (Figure 11). While it also wanted to achieve a 'balanced' community, this was to be done through creating a market for housing in the inner city by attracting private housebuilders. The problem was therefore not one of need but of 'market failure'. Directions from the DoE to the LDDC were explicit about this new focus. Successive drafts of the policy prepared during the summer of 1981 saw Ministers reinforce the emphasis on private builders and the role of housing associations. ${ }^{93}$ Its final drafts laid it down on page one that 'the principal policy objective is to attract private housebuilders to provide houses for owner occupation, particularly in the low/ middle income sector' ${ }^{94}$ At the House of Lords Inquiry a DoE official stated the aim was a tenure mix of $75 \%$ for sale. ${ }^{95}$ Perhaps aware of the opposition this might spark, a few days later Broackes - while under pressure at the same inquiry - committed the LDDC to a tenure mix of $50 \%$ for sale, $25 \%$ shared ownership and $25 \%$ publically rented. The mix of housing tenures, so important in the redevelopment of the whole area, was as much in flux and as uncertain as the governance and planning arrangements that remained so multi-faceted. The fact that by 1998, when the LDDC closed, the figures were $74 \%$ owner-occupied, $23 \%$ local authority or housing association rented and $3 \%$ shared ownership could be read as bearing out the inevitability of the market approach. ${ }^{96}$ However, that would obscure the LDDC's shift to embrace social regeneration in its 'second wave' after 1987, when it did did include substantial investment in social housing - indicating once again how policy was constantly evolving. ${ }^{97}$ 


\section{Conclusions: Eras and Alternatives}

The planning theorist Peter Marris has characterised the three stages of Docklands regeneration under consideration here as 'planning by design', presenting 'the physical representation of a future', which was first replaced by 'planning as strategy' and the 'co-ordination of actions', and then by 'planning as entrepreneurship' via 'the exploitation of resources and powers to achieve the organization's own designated purpose' ${ }^{98}$ But as we have seen - in terms of governance, the likely balance between manufacturing and white-collar jobs, and the types of housing tenure encouraged - there was little that was inevitable about this process. Nor were these eras distinct; the planning visions put forward often held within them contradictory elements and some ideas (for instance the concepts of New Town redevelopment and local government co-operation) reappear through time either as alternatives or more mainstream policies. Rather than identifying distinct eras, we would argue that there has been a constant tension between different approaches to regeneration. These have come together in different ways at different times to form provisional and contingent entities only to be constantly reassembled through the weight of their internal contradictions and external forces. In the process 'Docklands' has been made and remade both physically and as an idea.

It could be argued, instead, that policy approaches were assembled around competing ideas of "how the "problem" was defined'. ${ }^{99}$ The emphasis on language - protean, complex, and often unclear - is instructive. Attempts to regenerate Docklands in the 1970s defined the problem as one finding the right forms of state intervention to address economic decline and 'redress the deficiencies' in East London. These initiatives attempted to fuse traditional regional policy, and the spatial readjustment of manufacturing employment, with newer views of participation and citizenship. Not surprisingly, given the gaps that opened up between central government, the GLC, the boroughs and the residents, this attempt was the cause of as much conflict as it was productive of concert. The consequent confusion, and public sector spending constraints, then led to the re-definition of the problem as one of 'market failure', a failure that had been caused as much by the previous attempts at state intervention as economic forces. The solution was the imposition of a Development Corporation which itself accepted neither prior technocratic premises about guiding the location of jobs, nor the concept of community involvement as it had developed in the late 1960s and the 1970s.

But the break with the past can be exaggerated, and easy references to 'Three-D Thatcherism' can be refuted. The LDDC's nominal creators and overseers in the Thatcher Cabinet were divided as to whether spending such large sums and creating new centralised powers was wise; civil servants continued to think along New Town lines, partly motivated by frustration at the speed of redevelopment up to the early 1980s. The DJC had long attempted to attract or 'lever in' private sector investment; the LDDC in its turn spent money on social infrastructure. ${ }^{100}$ Further distinct 'eras' are the sites of constant re-imaging and reconstruction. The LDDC, for its part, always narrated the change in Docklands it initiated as inevitable, treating the area and its past redevelopment as a peculiar type of tabula rasa and suggesting that there were no alternatives to its 'successes'. The local population, it claimed, had, 'albeit grudgingly', recognised that 'with the final dock closure... future jobs would certainly have to come from new economic structures unrelated to the past' ${ }^{101}$ But these words, from the self-penned obituaries the LDDC commissioned on its demise in 1998, 
represent a deliberate re-writing of history that excludes the possibility of any alternatives and a post-hoc justification of what was a much more disordered and less inevitable process of policy assemblage. It was as varied and chaotic a process as were the social changes going on inside Docklands, fusing together old elements to make something new. Docklands contained elements of central state planning, neo-liberal tax-cutting and strenuous urban activism, just as its people came to think of themselves as rather different from suburbanites or gentrifiers across the rest of London. ${ }^{102}$

It was also a process which continued after 1998. Focusing on policy assemblage can help make sense of the often neglected post-LDDC regeneration of Docklands when the same tensions between levering in private investment and providing social infrastructure are evident. ${ }^{103}$ The Canary Wharf development, for example, has doubled in size since Tower Hamlets reasserted its control over the planning of the Isle of Dogs. In 2004 the London Plan under Mayor Livingstone (formerly, as Leader of the GLC, a vehement opponent of the LDDC's policies) identified East London as the priority regeneration area for London, creating a 'new kind of exemplary, sustainable world class urban quarter' based on promoting major commercial development while extracting value for social purposes, for example $50 \%$ affordable housing. ${ }^{104}$

Urban Development Corporations did in fact make a comeback in 2003, but in a very different policy assemblage depicted as 'benign' agencies working in partnership to assemble the land needed for New Labour's sustainable communities strategy rather than bypassing local government. ${ }^{105}$ Parts of the Victoria Dock in Newham again found themselves in an Enterprise Zone in 2011 as the Coalition Government sought to once again remove the burden of planning, but in times of austerity without the tax and capital incentives from the 1980s. ${ }^{106}$ And in 2014 the New Economics Foundation put forward an alternative plan for the City Airport in the Royals 'setting the standard... for a fairer and more sustainable future'. ${ }^{107}$ As one long-standing actor in Docklands regeneration said, 'if you stay in one place long enough history repeats itself, often in bizarre ways' ${ }^{108}$

The history of Docklands therefore shows not only how the area has been continuously remade but also that there were always other alternatives possible, such as more creative uses of public land, more effective ways of capturing development value for social uses, more 'bottom-up' planning procedures, and more sustained approaches to supporting existing port and employment uses which would similarly have led to a very different future for Docklands - as has become evident in different European cities. Further, and given the continuing fluidity and disputation around the development of Docklands and other areas like it, this more nuanced understanding highlights the need continually to re-assert and re-assemble alternative visions of regeneration: a task that remains as important today as it was in the 1970 s and 1980 s. 


\section{Bibliography}

Allmendinger, P. "From New Right to New Left in UK Planning." Urban Policy and Research 21, no. 1 (2003): 5779.

Anderson, B. and C. McFarlane. “Assemblage and Geography." Area 42, no. 2 (2011): 124-27.

Batley, R. "London Docklands: An Analysis of Power Relations between UDCs and Local Government." Public Administration 67, no. 2 (1989): 167-87.

Barnes, J., B. Colenutt and P. Malone. "London Docklands and the State." In Malone, P., ed. City, Capital and Water. London: Routledge, 2013: 15-36.

Brenner, N. and N. Theodore, eds. Spaces of Neoliberalism: Urban Restructuring in North America and Western Europe. Oxford: Wiley-Blackwell, 2002.

Brownill, S. Developing London Docklands. London: Paul Chapman, 1990.

Brownill, S. "London Docklands Revisited; The Dynamics of Waterfront Regeneration." In Desfor, G., Q. Stevens, and D. Schubert, eds. The Fixity and Flow of Waterfront Regeneration. New York: Routledge, 2011: 121-42.

Brownill, S. "Just Add Water, Waterfront Regeneration as A Global Phenomenon." In MacCarthy, M.E. and J. O'Leary, eds., A Companion to Urban Regeneration: Global Constraints, Local Opportunities. London: Routledge, 2013: 45-55.

Burton, P. "Planning Theory and Public Policy: An Analysis of Policies for the London Docklands," Unpublished PhD Thesis, University of Bristol, 1986.

Burton, P. "On the Waterfront: Changing Approaches to Planning in London's Docklands." Public

Administration 64, no. 3 (1986): 249-53.

Butler, T. "Re-Urbanizing London Docklands: Gentrification, Suburbanization or New Urbanism?" International Journal of Urban and Regional Research 31, no. 4 (2007): 759-81.

Carmona, M. "The Isle of Dogs: Four Development Waves, Five Planning Models, Twelve Plans, Thirty-Five Years, and a Renaissance... of Sorts." Progress in Planning 71, no. 3 (2009): 87-151.

Chapman, P. “A Deeper Look at the Docks." Architect's Journal 27, no. 1 (1973): 541-45.

Church, A. and M. Frost, "The Thames Gateway: An Analysis of the Emergence of a Sub-Regional Regeneration Initiative." The Geographical Journal 161, 2 (1995), pp. 199-209.

Cochran, A. "Just Another Failed Experiment." In Imrie, R. and H. Thomas, eds. Urban Development Corporations. London: Sage, 1999: 246-58.

Colenuttt, B. and J. Lowe. “Does London Need the Docklands Urban Development Corporation?” London Journal 7, no. 2 (1981): 235-38.

Crilley, D. "The Disorder of John Short's New Urban Order." Transactions of the Institute of British Geographers 15, no. 2 (1990): 232-38.

Darby, M. “A Local Resident's View.” In Hall, J. et al., eds. East London Papers 15 (1973): 30-36.

Day, E. “A Journey Across Margaret Thatcher's Britain." The Observer, 13 April 2013.

Docklands Borough Councils, Local Democracy Works: A Partnership in London Docklands: The Case against a 'New Town' (London: Greenwich Borough Council et al., 1979).

Docklands Development Team, Housing (London: Docklands Joint Committee, 1975).

Docklands Development Team, Transport (London: Docklands Joint Committee, 1975).

Docklands Joint Committee. A Strategy for Docklands, Setting the Scene: A Working Paper for Consultation. London: DJC, 1976.

Docklands Joint Committee. London Docklands Strategic Plan. London: DJC, 1976.

Docklands Joint Committee. London Docklands Operational Programme, 1979-83: The Years of Growth. London: DJC, 1979.

Evans, E.J. Thatcher and Thatcherism. London: Routledge, rev. edn., 2013.

Eversley, D.E. The Re-Development of London Docklands: A Case Study in Sub-Regional Planning. London:

Regional Studies Association, 1975.

Faulconbridge, G. and A. Osborn. "Thatcher's Legacy: A Citadel of Finance atop Once-Derelict Docks http://uk.reuters.com/article/2013/04/16/uk-britain-thatcher-wharf-idUKBRE93F0S920130416, accessed 11 February 2013.

Florio, S. and S. Brownill. "Whatever Happened To Criticism? Interpreting the LDDC's Obituary." City 4, no. 1 (2000): 53-64.

Foster, J. Docklands: Cultures in Conflict, Worlds in Collision. London: UCL Press, 1999.

Greater London Council (GLC). Greater London Development Plan. London: GLC, 1969. 
GLC. The East London File. London: GLC, 1983.

Greater London Authority. The London Plan. London: GLA. 2004.

Hall, J. "The LDDC's Policy Aims and Methods." In Ogden, P.E., ed. London Docklands: The Challenge of

Development. Cambridge: Cambridge University Press, 1992: 18-24.

Hargreaves, I. "Port of London State Aid Continues." Financial Times, 28 July 1979.

Heseltine, M. Life in the Jungle: My Autobiography. London: Hodder and Stoughton, 2000.

House of Commons. Redevelopment of London Docklands: Minutes of Evidence, February 1979. London: HMSO, 1979.

House of Commons Expenditure Committee. Fifth Report: The Redevelopment of London Docklands, April 1975. London: HMSO, 1975.

House of Commons. The Employment Effect of UDCs: Employment Committee Third Report. London: HMSO, 1988.

House of Lords. Report of the House of Lords Select Committee on the London Docklands Development Corporation Area and Constitution Order. London: HMSO, 1981.

Jones, P. and J. Evans. Urban Regeneration in the UK. London: Sage, 2008.

Keith, M. "Figuring City Change: Understanding Urban Regeneration in Britain's Thames Gateway." In Imrie, R., L. Lees, and M. Raco, eds. Regenerating London: Governance, Sustainability and Community in a Global City, London: Routledge, 2009: 75-92.

London Docklands Study Team. Docklands: Redevelopment Proposals for East London. London: Travers Morgan and Partners, London, 1973, Vol. I.

London Docklands Development Corporation (LDDC). Annual Report and Accounts for 1981-82. London: LDDC, 1982.

LDDC. Royal Docks Area Development Framework. London: LDDC, 1984.

LDDC. Starting From Scratch: The Development of Transport in London Docklands. London: LDDC, 1997.

LDDC. Housing in the Renewed London Docklands: A Major Contribution to Capital Living. London: LDDC, 1998.

LDDC. Employment: New Jobs and Opportunities. The Employment Strategy of London Docklands Development Corporation. London: LDDC, 1998.

LDDC. History Pages. The London Docklands Development Corporation; Telling the Story. Available at http://www.lddc-history.org.uk/index.html.

Marris, P. Meaning and Action, Routledge: London, 1982.

McCann, E. and K. Ward. "Assembling Urbanism: Following Policies and "Studying Through" the Sites and Situations of Policy Making." Environment and Planning A 44, no. 1 (2012): 42-51.

McCann, E., A. Roy and K. Ward. “Assembling/ Worlding Cities.” Urban Geography 34, no. 5 (2013): 581-89.

Ministry of Housing and Local Government. A Strategy for the South East. London: HMSO, 1967.

Ministry of Housing and Local Government. Strategic Plan for the South East. London: HMSO, 1970.

New Economics Foundation. An Alternative Vision for the Royal Docks. Available at

http://www.neweconomics.org/blog/entry/an-alternative-vision-for-the-royal-docks.

Newham Dockland Forum, The People's Plan for the Royal Docks, Newham: Docklands Forum, 1983.

Raco, M. "A Step Change or a Step Back? The Thames Gateway and the Re-Birth of the UDCs." Local Economy 20, no. 2 (2005): 141-53.Riddell, P. "Special Agency to Redevelop London Docklands." Financial Times, 15 September 1973.

Schubert, D. "Waterfront Revitalisation: From a Local to a Regional Perspective in London, Rotterdam, Hamburg and Barcelona." In Desfor, Stevens, and Schubert, eds. Fixity and Flow: 74-100.

Short, J.R. "Yuppies, Yuffies and the New Urban Order." Transactions of the Institute of British Geographers 14, no. 2 (1989): 173-88.

Thornley, A. Urban Planning Under Thatcherism: The Challenge of the Market. London: Routledge, 1991.

Weiler, P. "Labour and the Land: The Making of the Community Land Act, 1976." Contemporary British History 27, no. 4 (2013): 389-420.

White, J. London in the Twentieth Century (London: Random House, 2008 edn.). 


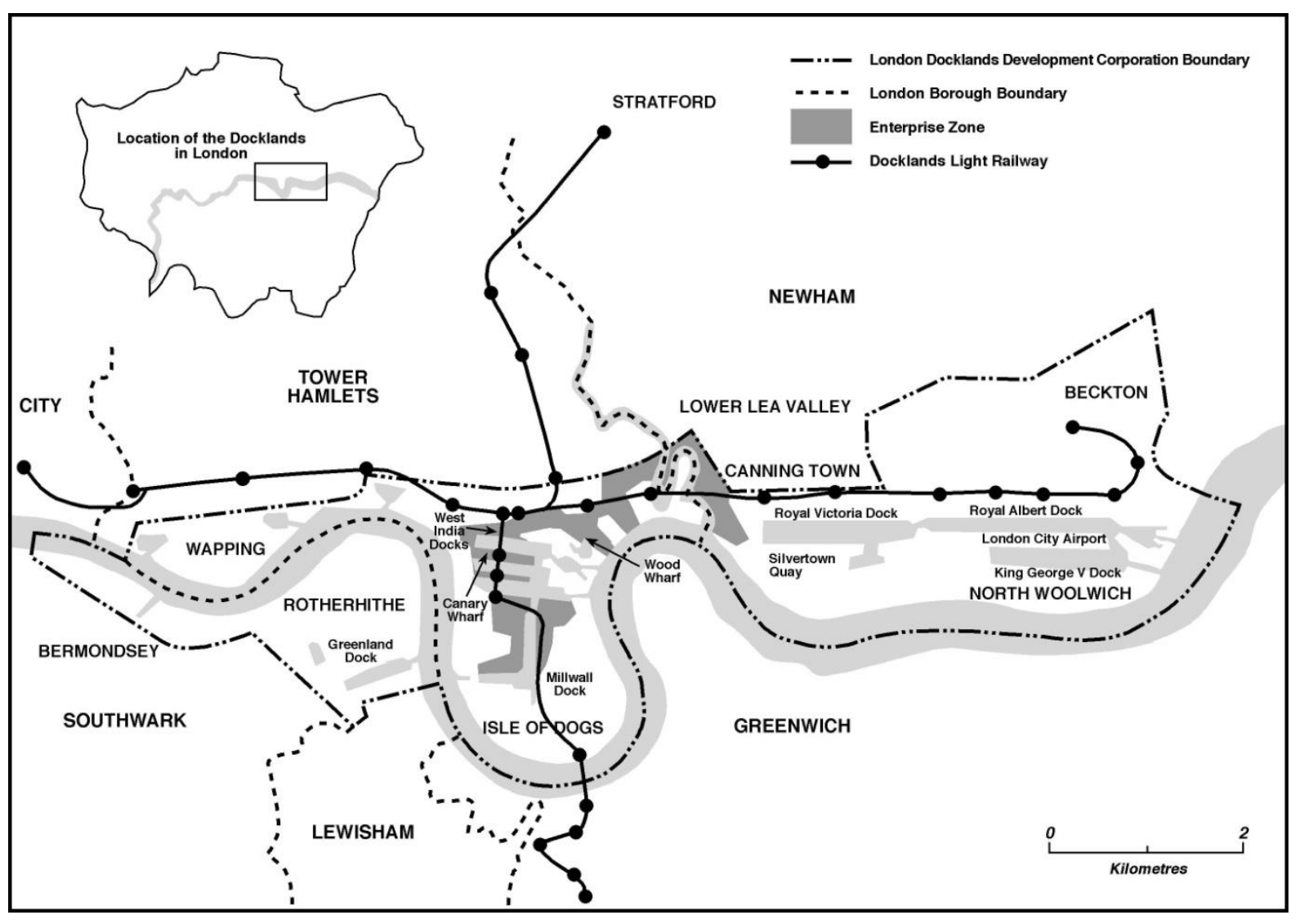

Map one 


\begin{tabular}{|c|c|c|c|c|c|c|}
\hline $\begin{array}{l}\text { National } \\
\text { Government }\end{array}$ & $\begin{array}{l}\text { Greater } \\
\text { London } \\
\text { Council }\end{array}$ & Southwark & $\begin{array}{l}\text { Tower } \\
\text { Hamlets }\end{array}$ & Lewisham* & Newham & Greenwich* \\
\hline $\begin{array}{l}\text { 1970-1974: } \\
\text { Conservative }\end{array}$ & $\begin{array}{l}\text { 1970-73: } \\
\text { Conservati } \\
\text { ve }\end{array}$ & $\begin{array}{l}\text { 1971-20002: } \\
\text { Labour }\end{array}$ & $\begin{array}{l}\text { 1971- } \\
\text { 1986: } \\
\text { Labour }\end{array}$ & $\begin{array}{l}\text { 1971-2006: } \\
\text { Labour }\end{array}$ & $\begin{array}{l}\text { 1971- } \\
\text { Present: } \\
\text { Labour }\end{array}$ & $\begin{array}{l}\text { 1971- } \\
\text { Present: } \\
\text { Labour }\end{array}$ \\
\hline $\begin{array}{l}\text { 1974-1979: } \\
\text { Labour }\end{array}$ & $\begin{array}{l}1973- \\
\text { 1977: } \\
\text { Labour }\end{array}$ & $\begin{array}{l}\text { 2002-2010: } \\
\text { Liberal } \\
\text { Democrat } \\
\text { (in coalition } \\
\text { with } \\
\text { Conservative } \\
\text { s after 2006) }\end{array}$ & $\begin{array}{l}\text { 1986- } \\
\text { 1994: } \\
\text { Liberal/ } \\
\text { Social } \\
\text { Democrati } \\
\text { c Party/ } \\
\text { Liberal } \\
\text { Democrat } \\
\text { s }\end{array}$ & $\begin{array}{l}\text { 2006-2010: } \\
\text { Labour (via } \\
\text { executive, } \\
\text { electoral } \\
\text { mayoralty: } \\
\text { council, no } \\
\text { overall control) }\end{array}$ & & \\
\hline $\begin{array}{l}\text { 1979-1997: } \\
\text { Conservative }\end{array}$ & $\begin{array}{l}\text { 1977- } \\
\text { 1981: } \\
\text { Conservati } \\
\text { ve }\end{array}$ & $\begin{array}{l}\text { 2010- } \\
\text { Present: } \\
\text { Labour }\end{array}$ & $\begin{array}{l}\text { 1994- } \\
\text { Present: } \\
\text { Labour }\end{array}$ & $\begin{array}{l}\text { 2010-Present: } \\
\text { Labour }\end{array}$ & & \\
\hline $\begin{array}{l}\text { 1997-2010: } \\
\text { Labour }\end{array}$ & $\begin{array}{l}\text { 1981- } \\
\text { 1986: } \\
\text { Labour } \\
\text { (abolished, } \\
1986 \text { ) }\end{array}$ & & & & & \\
\hline & & & & & & \\
\hline
\end{tabular}

*Not included in Docklands area post-1981

\section{Table one}




\begin{tabular}{|c|c|c|}
\hline 1968 & First upstream dock closes & $\begin{array}{l}\text { Start of piecemeal redevelopment at St Katherine Docks by } \\
\text { then GLC; mix of public and private developments and } \\
\text { housing. }\end{array}$ \\
\hline 1973 & Travers Morgan study published & \\
\hline 1974 & $\begin{array}{l}\text { Docklands Joint Committee } \\
\text { established }\end{array}$ & \\
\hline 1976 & $\begin{array}{l}\text { London Docklands Strategic Plan } \\
\text { published by partnership of Labour } \\
\text { local authorities and central } \\
\text { government }\end{array}$ & $\begin{array}{l}\text { Aimed at 'redressing the imbalances' of East London; plan- } \\
\text { led, underpinned by Keynesian economics. }\end{array}$ \\
\hline 1979 & $\begin{array}{l}\text { Announcement of creation of Urban } \\
\text { Development Corporations in } \\
\text { Liverpool and London by first Thatcher } \\
\text { administration }\end{array}$ & \\
\hline 1981 & LDDC formally opens for business & $\begin{array}{l}\text { Governance form and strategies aimed at addressing } \\
\text { market failure; sparked widespread local opposition. }\end{array}$ \\
\hline 1982 & $\begin{array}{l}\text { Enterprise Zone created on Isle of } \\
\text { Dogs }\end{array}$ & $\begin{array}{l}\text { Tax and financial incentives; removal of need for planning } \\
\text { permission in EZ. }\end{array}$ \\
\hline 1984 & $\begin{array}{l}\text { People's Plan for the Royal Docks } \\
\text { published }\end{array}$ & $\begin{array}{l}\text { Grass roots planning-inspired alternative to London City } \\
\text { Airport plans launched in Poplar. }\end{array}$ \\
\hline 1985 & Initial Canary Wharf scheme proposed & \\
\hline 1986 & GLC abolished & \\
\hline $1987 / 88$ & $\begin{array}{l}\text { DLR and London City Airport open } \\
\text { Olympia and York take over Canary } \\
\text { Wharf scheme } \\
\text { Conservative government re-elected }\end{array}$ & $\begin{array}{l}\text { Land and property markets soar; planning gain deals signed; } \\
\text { second Wave and 'social regeneration' begins; LDDC } \\
\text { Community Services Division established. }\end{array}$ \\
\hline 1990 & Jubilee Line extension approved & \\
\hline 1992 & $\begin{array}{l}\text { Economic downturn } \\
\text { Decision to wind down UDCs taken }\end{array}$ & CSD closed; Canary Wharf goes into receivership. \\
\hline 1997 & Election of New Labour government & \\
\hline 1998 & $\begin{array}{l}\text { LDDC closes } \\
\text { Planning control reverts to Boroughs }\end{array}$ & $\begin{array}{l}\text { Upturn in markets enables LDDC to leave on a 'high'; LDDC } \\
\text { writes its own obituary stressing partnership and outputs. }\end{array}$ \\
\hline 1999 & $\begin{array}{l}\text { Greater London Authority established } \\
\text { with strategic planning powers } \\
\text { Ken Livingstone elected as Labour } \\
\text { Mayor } \\
\text { Jubilee Line opens }\end{array}$ & Increasing complexity of governance in the area. \\
\hline 2003 & $\begin{array}{l}\text { Sustainable Communities Action Plan } \\
\text { published by Central Government } \\
\text { including establishment of Thames } \\
\text { Gateway Growth Area }\end{array}$ & $\begin{array}{l}\text { Attention shifted to regional and sub-regional levels; } \\
\text { ideology of sustainable communities as driver for } \\
\text { regeneration. }\end{array}$ \\
\hline 2004 & $\begin{array}{l}\text { London Plan published by GLA } \\
\text { UDCs established by central } \\
\text { government in London Thames } \\
\text { Gateway and Thurrock }\end{array}$ & $\begin{array}{l}\text { Attempts to merge competitiveness and cohesion within } \\
\text { overall strategic framework. }\end{array}$ \\
\hline 2005 & $\begin{array}{l}\text { Choice of London for } 2012 \text { Olympics } \\
\text { announced }\end{array}$ & Stratford site becomes focus for regeneration. \\
\hline
\end{tabular}




\begin{tabular}{|l|l|l|}
\hline 2008/09 & $\begin{array}{l}\text { Election of Conservative Boris Johnson } \\
\text { as new Mayor of London } \\
\text { Global financial crisis }\end{array}$ & $\begin{array}{l}\text { Relaxing of some focus on planning gain and social } \\
\text { objectives; greater reliance on public funding for key sites } \\
\text { such as Olympics; major schemes such as Silvertown Quays } \\
\text { stalled. }\end{array}$ \\
\hline 2010 & Coalition government elected & \\
\hline 2011 & $\begin{array}{l}\text { Establishment of Enterprise Zone in } \\
\text { Royal Docks }\end{array}$ & $\begin{array}{l}\text { Establishment of Mayoral } \\
\text { Development Corporation on Olympic } \\
\text { site }\end{array}$ \\
\hline
\end{tabular}

Table two 


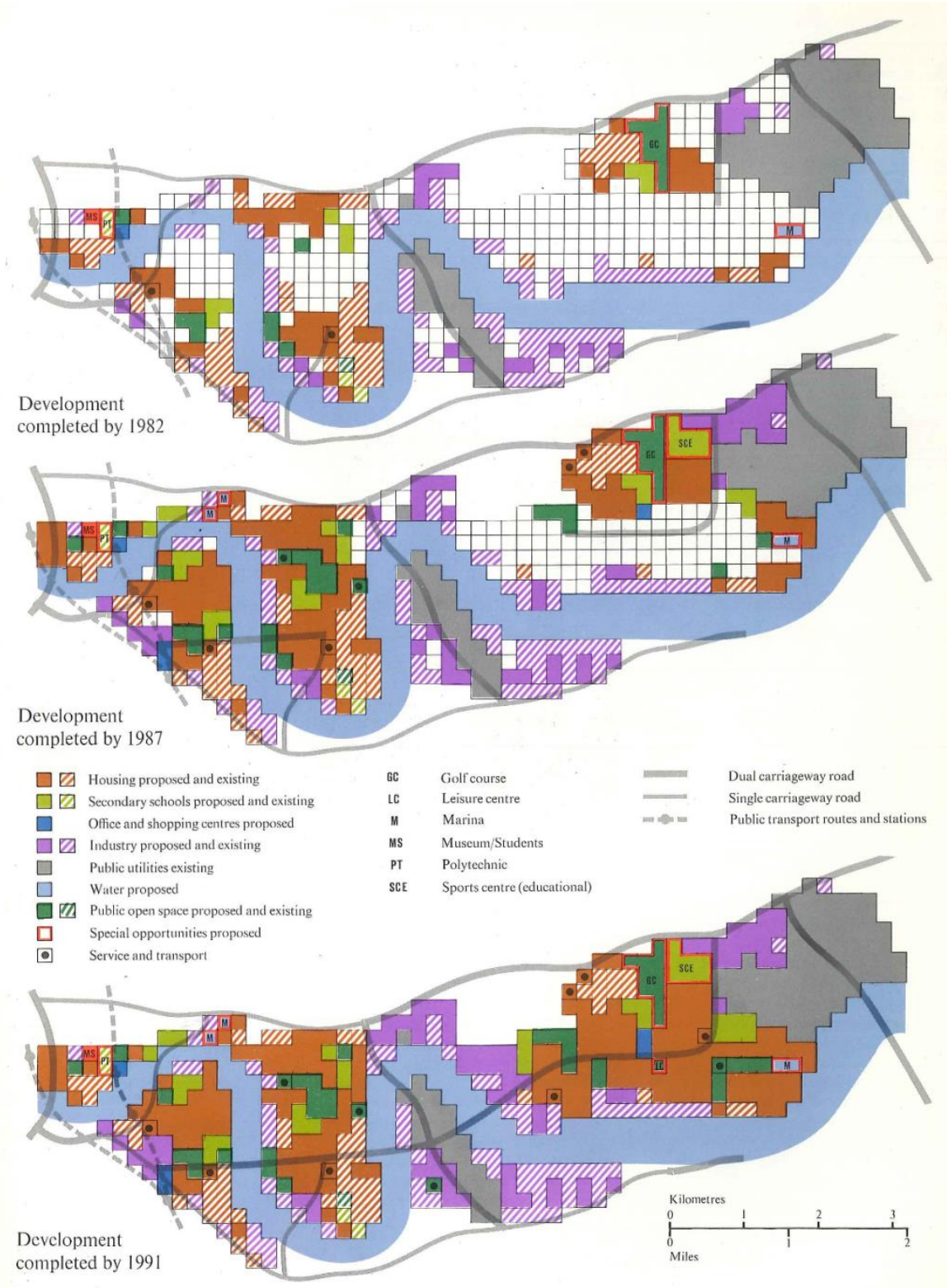

Figure 36.03 Broad phasing of 'East End Consolidated' (plan O) 1978-91

\section{Figure one}




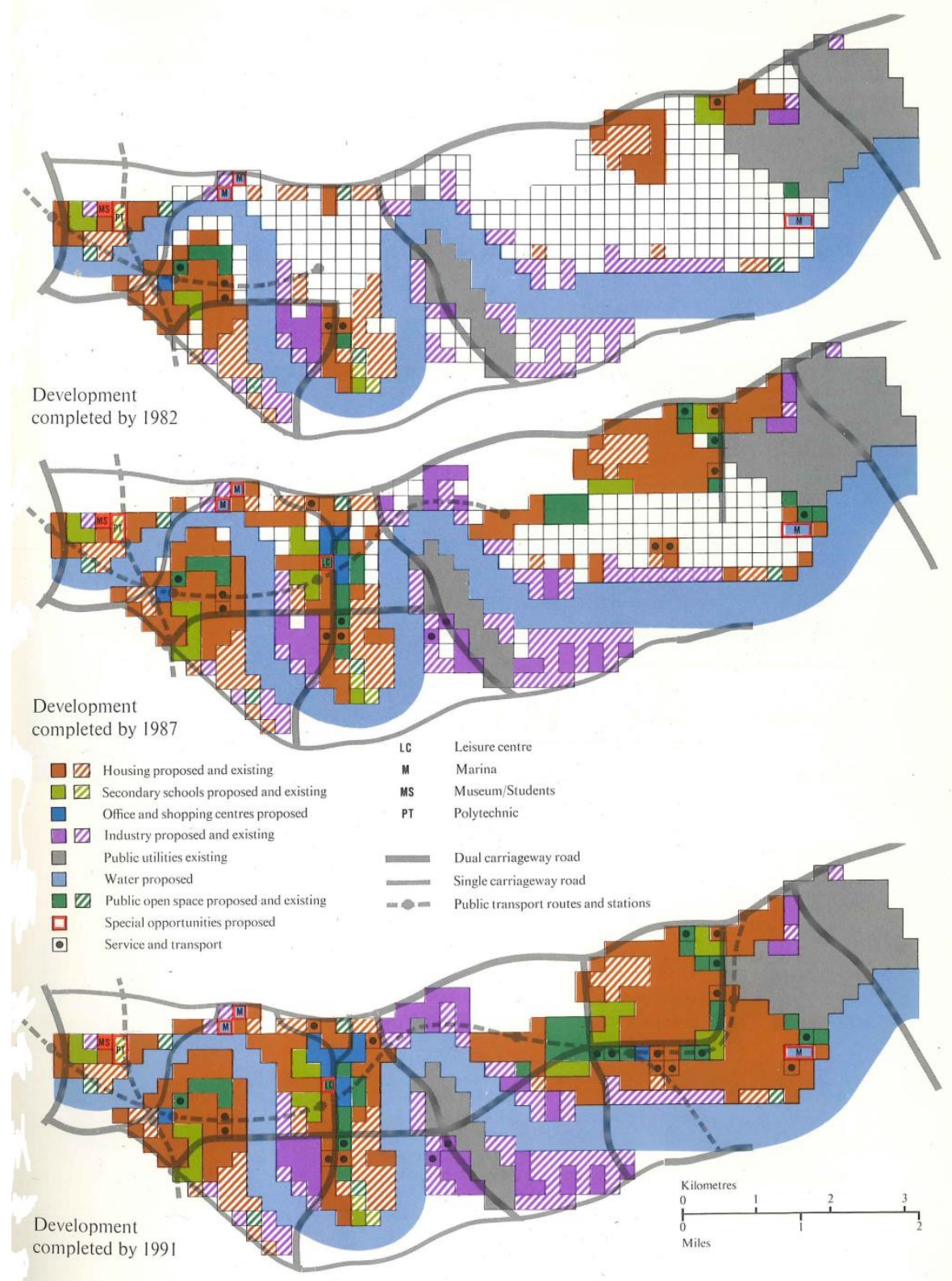

Figure 38.03 Broad phasing of 'City New Town' (plan W) 1978-91

Figure two 


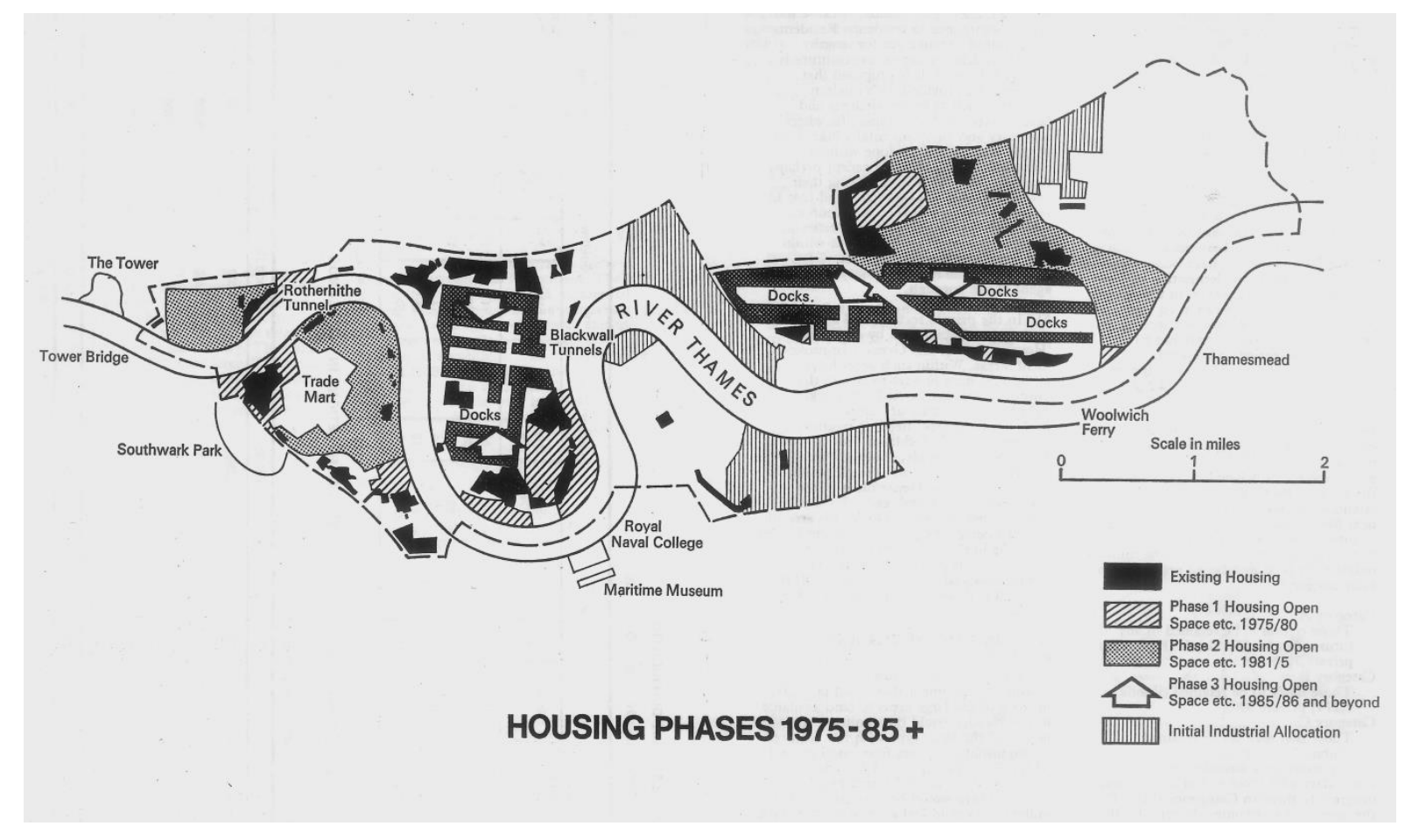

Figure three 


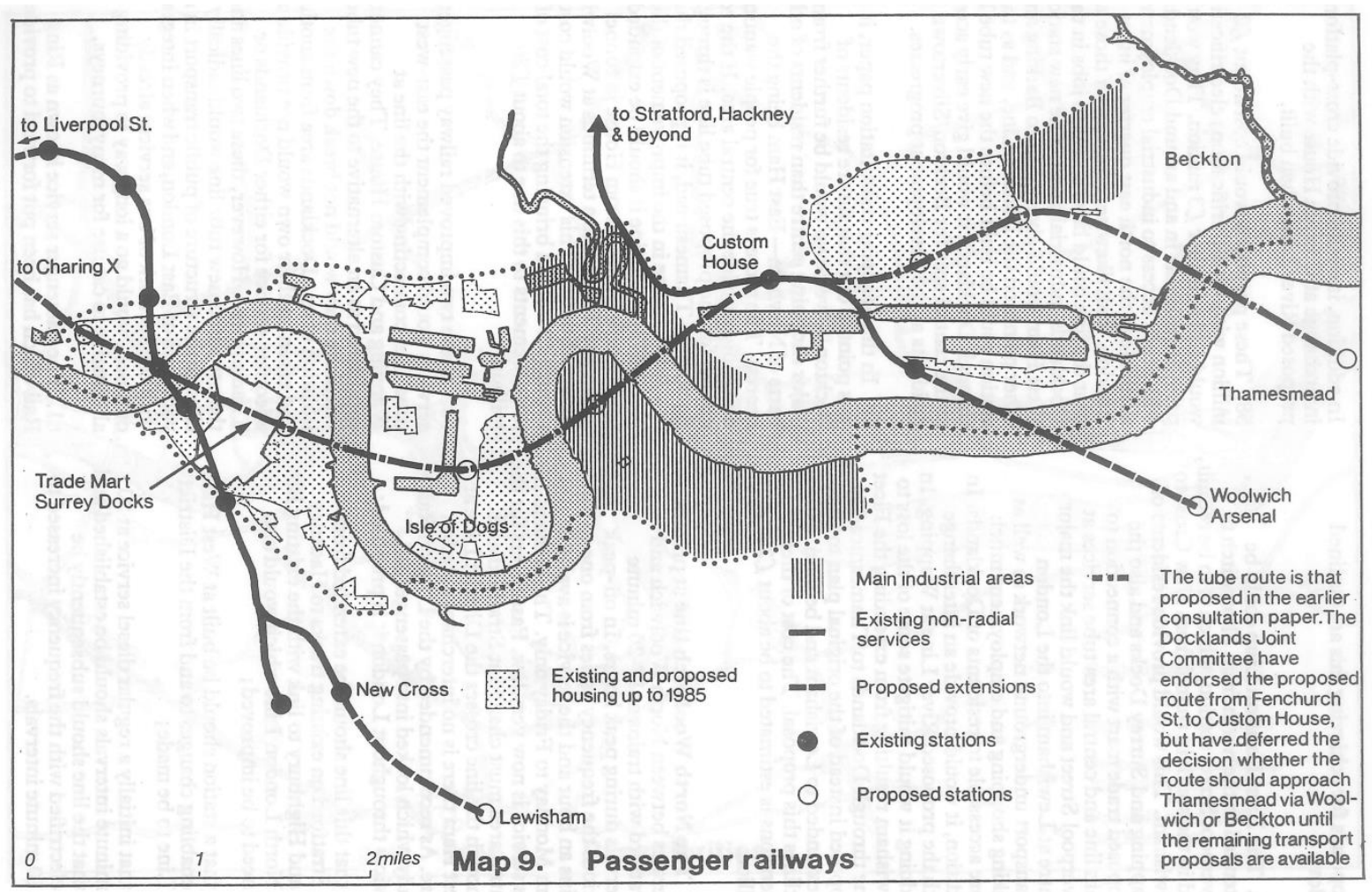

Figure four 


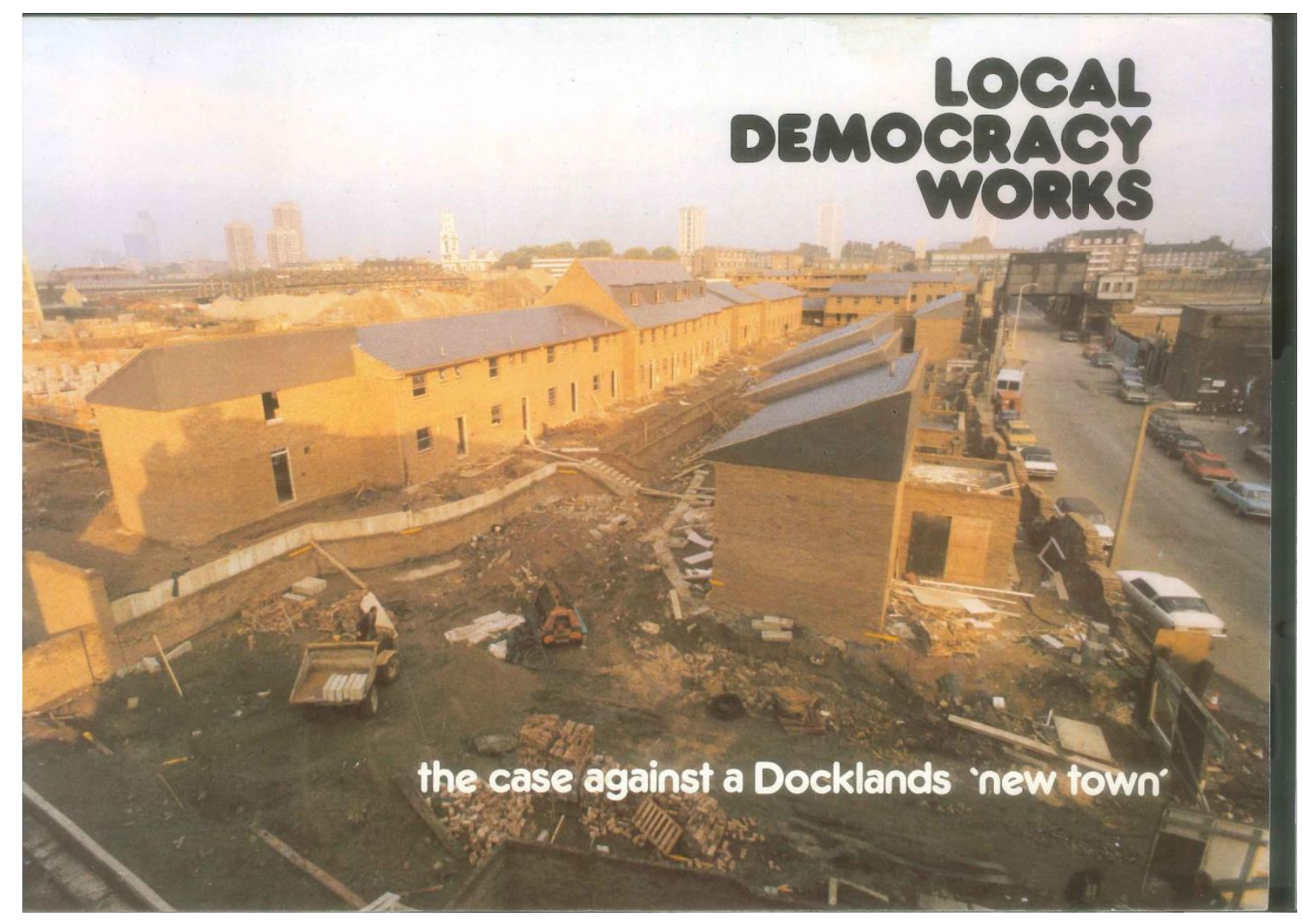

Figure five 


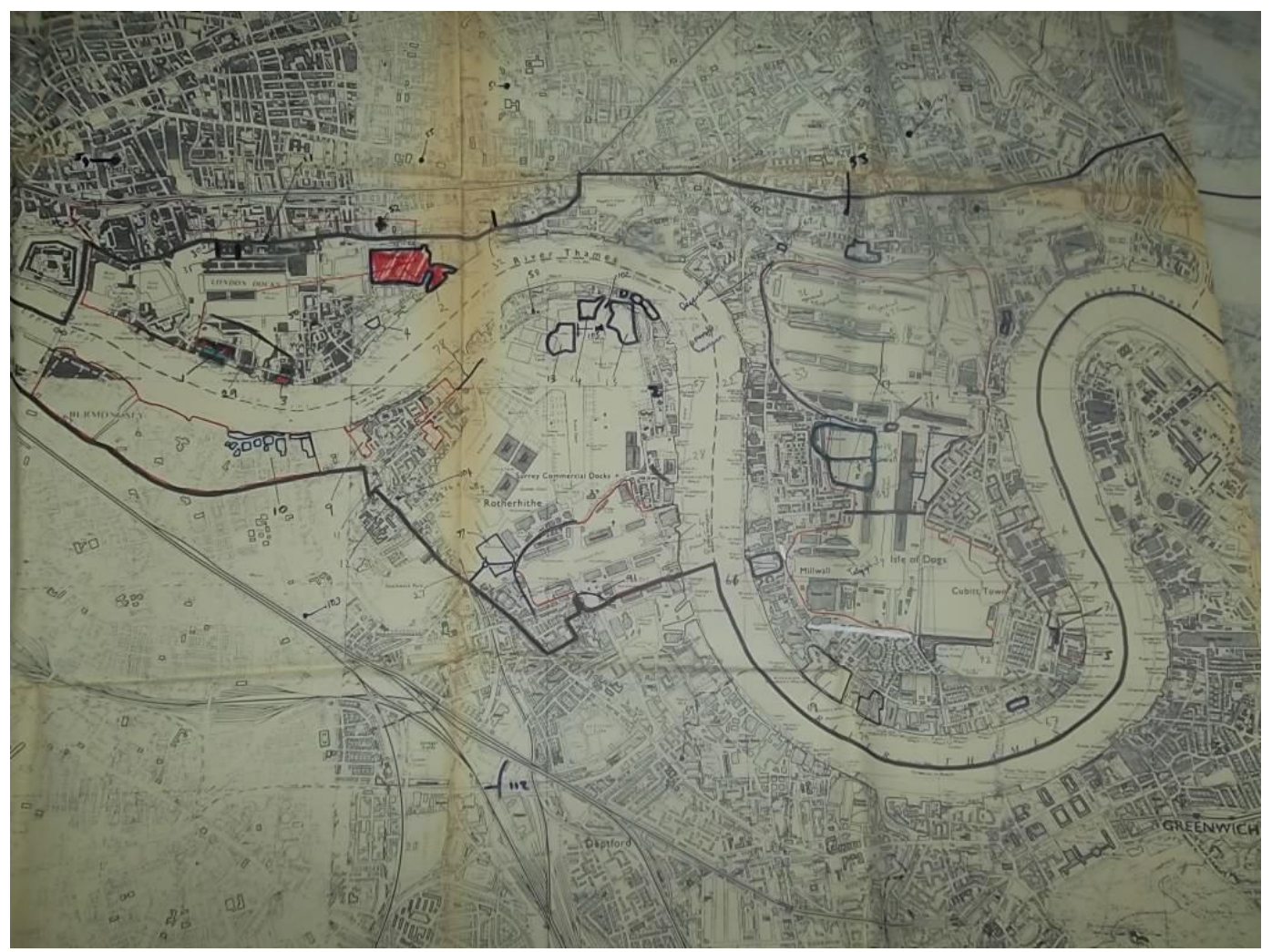

Figure Six 


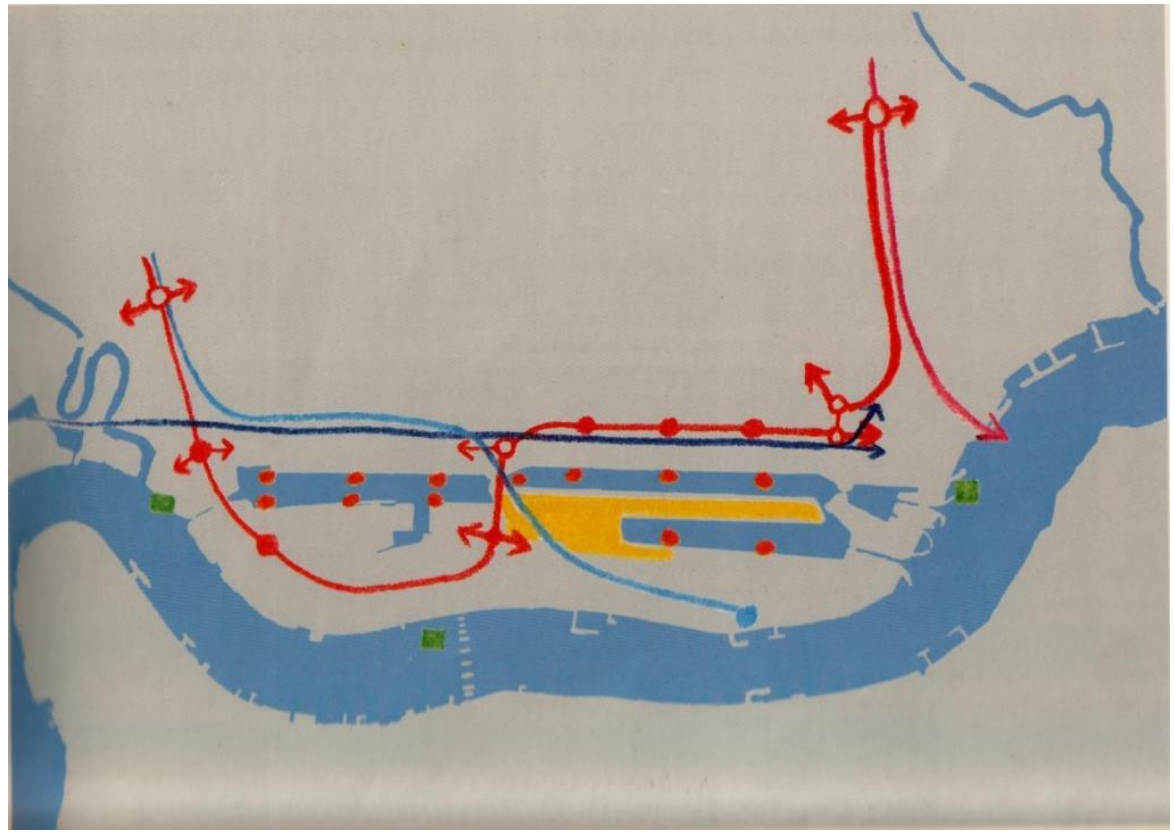

Figure seven 


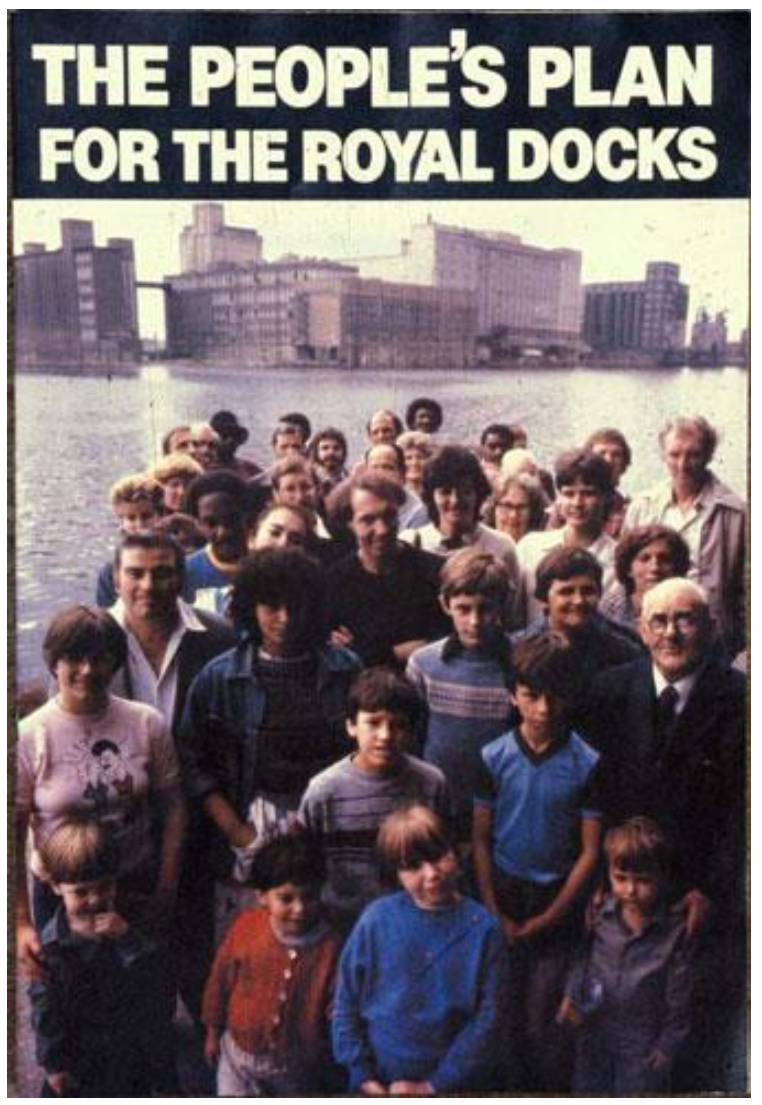

Figure eight 


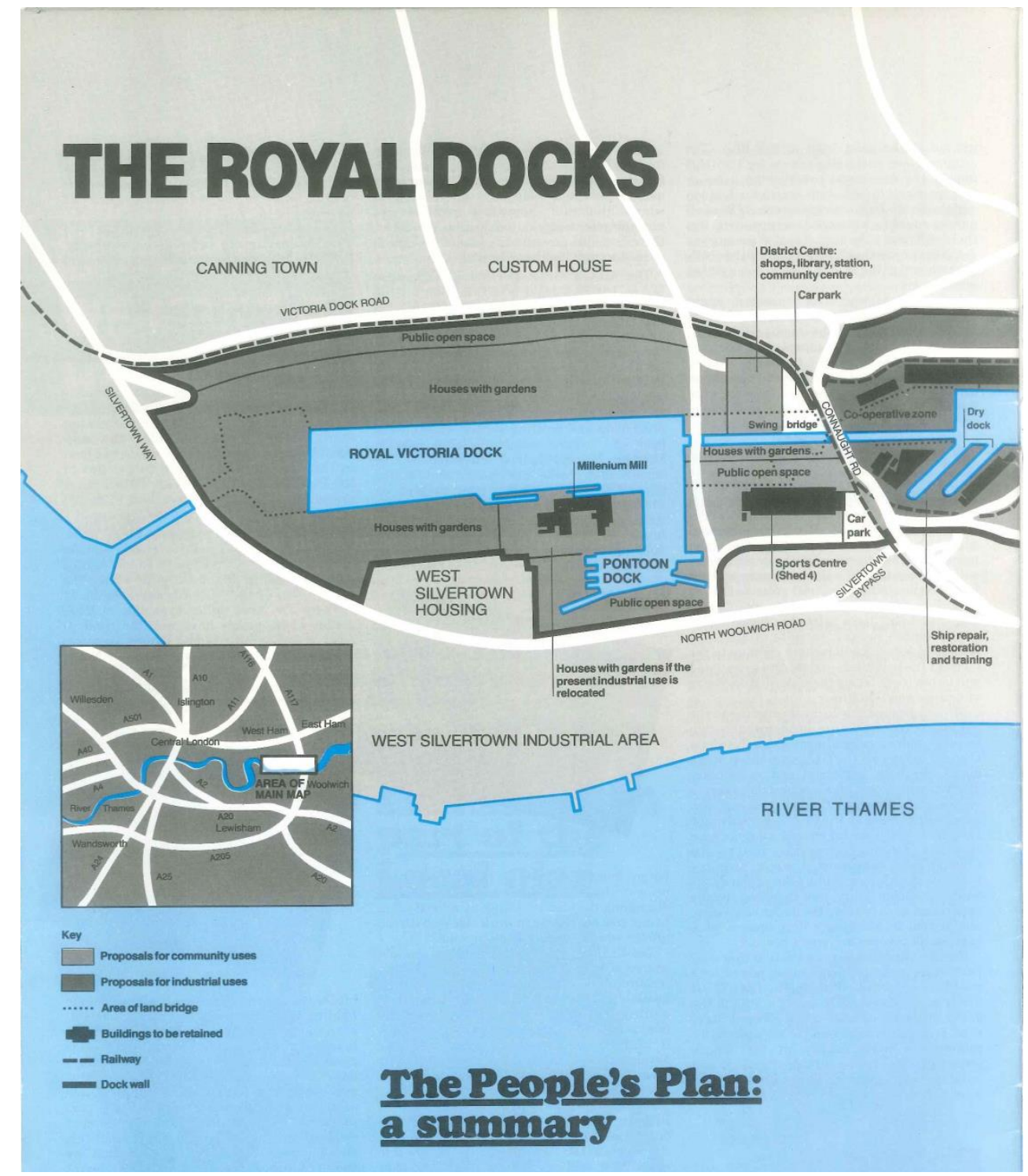

Figure nine (a) 


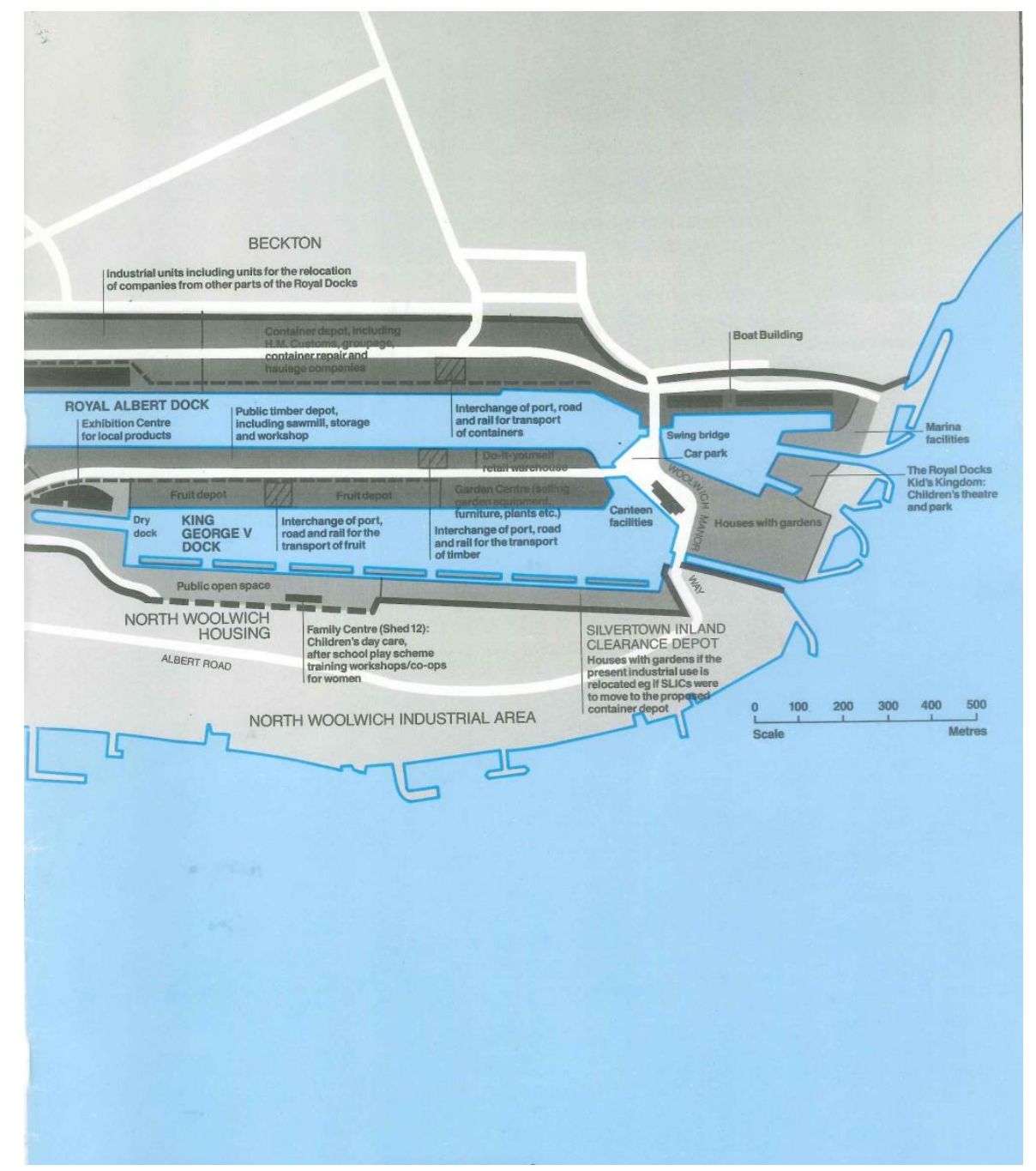

Figure nine (b) 


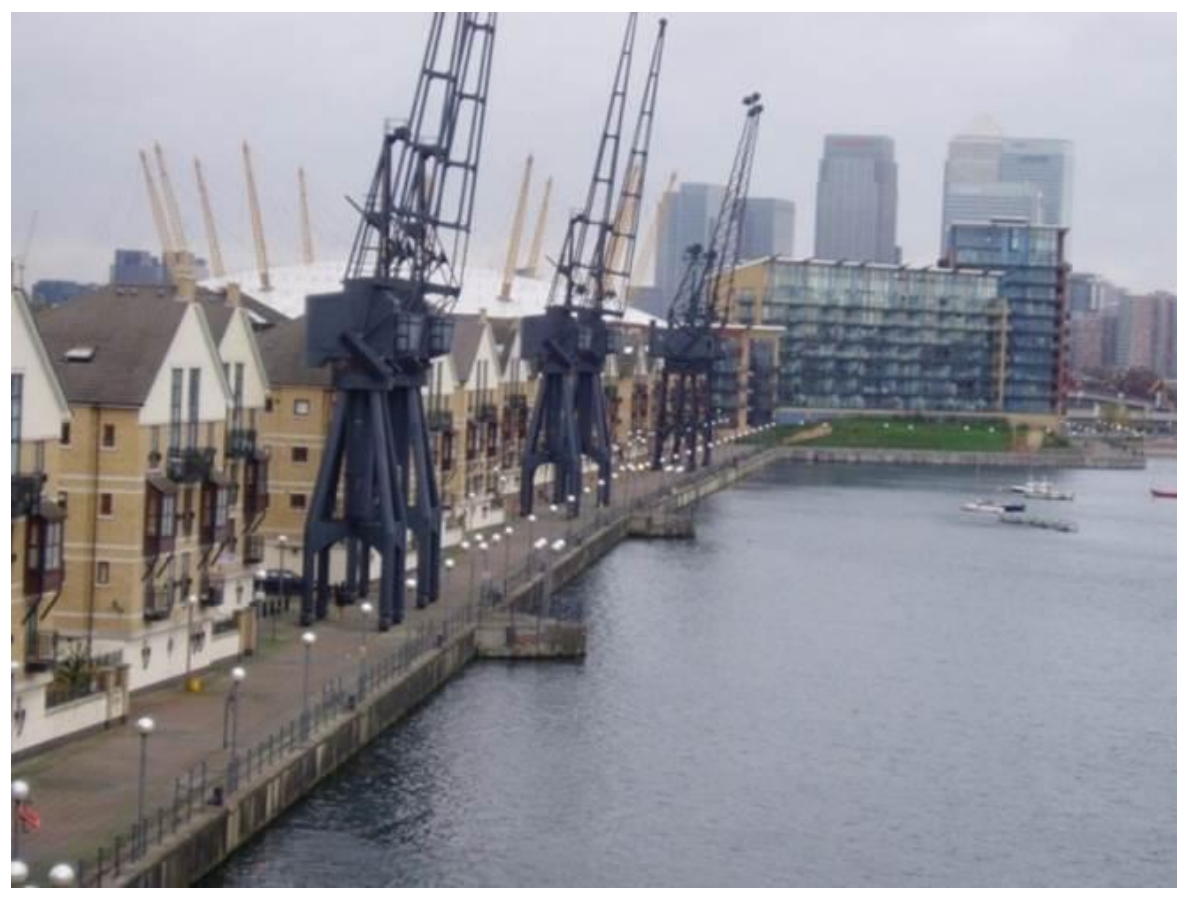

Figure ten 


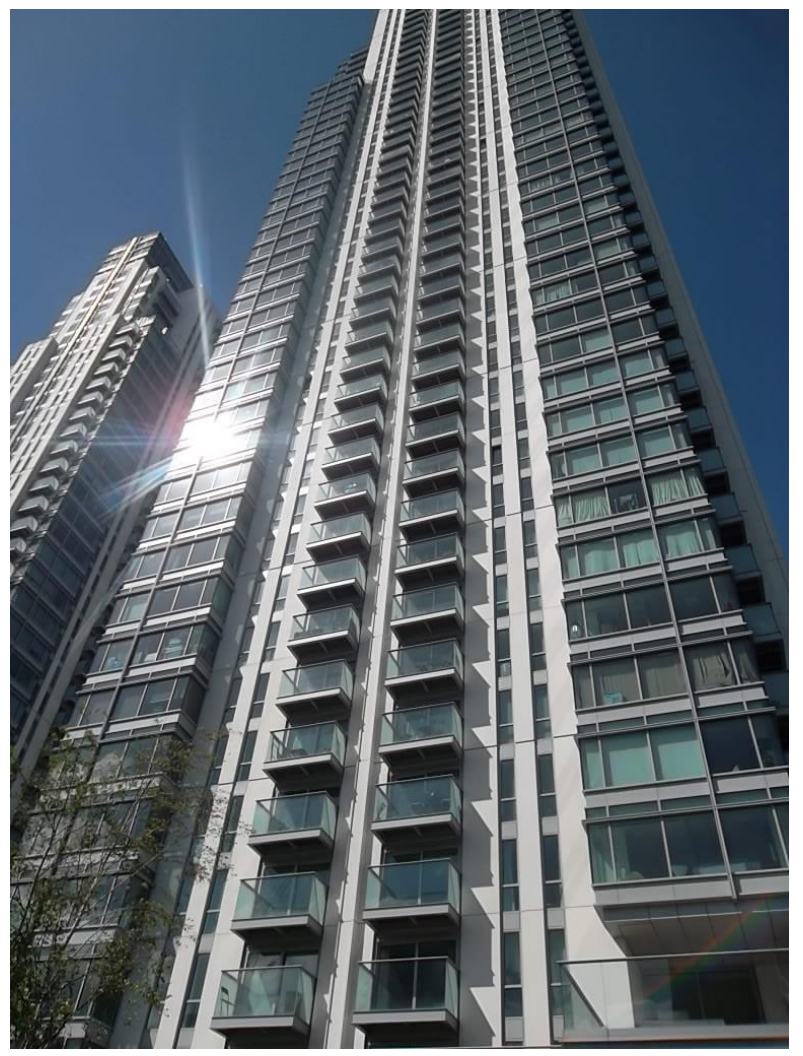

Figure eleven 
${ }^{1}$ Brownill, Developing London Docklands; Brownill, "Docklands Revisited"; Marris, Meaning; Carmona, "Isle of Dogs".

${ }^{2}$ White, London, 205.

${ }^{3}$ e.g. Ministry of Housing and Local Government, South East, 30-1; Ministry of Housing and Local Government, Strategic Plan, 43-4; GLC, Development Plan, 89-91. See Church and Frost, “Thames Gateway," 199-200.

${ }^{4}$ Marris, Meaning, 49.

${ }^{5}$ Barnes, Colenutt and Malone, "Docklands", 21-2; Brownill, “Docklands Revisited".

${ }^{6}$ The National Archives of the United Kingdom, Kew (hereafter TNA) PREM 16/2115, Gilbert to Barnett, 17 December 1975.

${ }^{7}$ TNA AT 88/111, Department of the Environment Press Notice No. 390, 14 September 1979.

${ }^{8}$ Florio and Brownill, "Whatever Happened to Criticsm?" 56.

${ }^{9}$ Brownill, “Docklands Revisited".

${ }^{10}$ Carmona, "Isle of Dogs".

${ }^{11}$ Allmendinger, "New Right to New Left".

${ }^{12}$ Keith, "Figuring City Change".

${ }^{13}$ Faulconbridge and Osborn, "Thatcher's Legacy"; Day, "Journey”.

${ }^{14}$ See http://www.lddc-history.org.uk/index.html, accessed 16 July 2014.

${ }^{15}$ McCann and Ward, 'Assembling Urbanism".

${ }^{16}$ See Short, "New Urban Order", esp. 178-85; Crilley, “Disorder", esp. 233-4.

${ }^{17}$ See Anderson and McFarlane, "'Assemblage and Geography", and McCann, Roy and Ward, "Assembling/ Worlding Cities".

${ }^{18}$ The authors wish to acknowledge support from the British Academy (small grant no. 100562) and Oxford Brookes University Central Research Fund in carrying out this work.

${ }^{19}$ TNA HLG 135/36, London Docklands Study Team, “Informal note on the long list of options”, 24 May 1972.

${ }^{20}$ Chapman, "Deeper Look".

${ }^{21}$ London Docklands Study Team, Redevelopment Proposals, Vol. I, 49. 
${ }^{22}$ House of Commons Expenditure Committee, Fifth Report, xiii.

${ }^{23}$ JDAG evidence to the House of Commons Expenditure Committee, in House of Commons, Redevelopment of London Docklands, 91, 98-9.

${ }^{24}$ Eversley, London Docklands, 10-12.

${ }^{25}$ Darby, “Resident's View," 30-36.

${ }^{26}$ TNA AT 41/134/1, Brain to Rhodes, 17 July 1973; Riddell, "Special Agency".

${ }^{27}$ TNA HLG 41/134/2, Southwark Borough Council to Rippon, 15 February 1973, Swaffield to Brain, 9 March 1973, Swaffield to Brain, 1 June 1973, Brain to Ward, 5 June 1973.

${ }^{28}$ Batley, “Docklands," 170.

${ }^{29}$ Docklands Joint Committee, Strategy, 2.

${ }^{30}$ TNA AT 88/13, Docklands Joint Committee resolutions, 19 July 1976; Docklands Joint Committee, Setting the Scene, 24 and fig. $2 \mathrm{~A}, 25$.

${ }^{31}$ On this see Weiler, "Labour and the Land".

${ }^{32}$ DJC, Setting the Scene, Appendix A, 31-2.

${ }^{33}$ Burton, "On the Waterfront," 350-1.

${ }^{34}$ GLC, East London, 31.

${ }^{35}$ TNA AT 88/13, Docklands Land Board memorandum, April 1977.

${ }^{36}$ Brownill, Developing London's Docklands, 29.

${ }^{37}$ TNA AT 88/2 275, GLC minutes, 16 June 1981.

${ }^{38}$ TNA CAB 165/112, Joseph to Thatcher, 3 July 1979.

${ }^{39}$ TNA AT 81/125, Garlick to Broackes, 15 November 1979.

${ }^{40}$ Local Government, Planning and Land Act 1980, http://www.legislation.gov.uk/ukpga/1980/65/contents, accessed 25 April 2014.

${ }^{41}$ TNA CAB 134/4337, Howe memorandum to Ministerial Committee on Economic Strategy, 14 December 1979; TNA CAB 134/4335, Ministerial Committee on Economic Strategy, minutes, 19 December 1979; TNA PREM 19/340, Howe to Thatcher, 29 February 1980.

${ }^{42}$ Interview with former Director of Royal Docks Team for LDDC, 5 August 2011.

${ }^{43}$ Thornley, Urban Planning. 
${ }^{44}$ See e.g. Brenner and Theodore, Spaces of Neoliberalism.

${ }^{45}$ Evans, Thatcher and Thatcherism, 22-3.

${ }^{46}$ TNA AT 88/111, UDCs Industrial Development and Promotion, 15 August 1979.

47 ibid., "Docklands: The options for Machinery Resources and process," 18 July 1979.

${ }^{48}$ TNA AT 88/124, Howe to Heseltine, “Inner cities policy," 21 August 1979.

${ }^{49}$ Heseltine, Life in the Jungle, 213.

50 TNA AT88/111, “UDCs: Industrial Development and Promotion,” 15 August 1979.

${ }^{51}$ ibid., "Treatment In PESC of Urban Development Corporations," 22 August 1979

52 Cochrane, "Urban Experiment".

${ }^{53}$ TNA 88/111, Gunn to Evans, 24 August 1979.

${ }^{54}$ TNA AT 41/390, Heseltine meeting with Docklands local authority leaders, minutes, 15 October 1979.

${ }^{55}$ TNA AT 81/125, Local borough leaders' meeting with Heseltine, Broackes, minutes, 7 February 1980.

${ }^{56}$ TNA AT 41/390, Greenwich Chief Executive to Department of the Environment, 28 November 1979, Rendell memorandum for Heseltine, 12 October 1979.

${ }^{57}$ Brownill, Developing London's Docklands.

58 TNA AT 81/231, DoE memorandum, “Discussion with John Pearson,” 1 June 1981.

${ }^{59}$ House of Lords, Report, paras. 6.1-6.8.

${ }^{60}$ TNA AN 81/215, Garlick meeting with Ward, minutes, 16 March 1981, Ward to Garlick, 24 March 1981, Jones to Garlick, 13 April 1981, Garlick to Ward, 13 April 1981.

${ }^{61}$ ibid., Jones to McQuial, 18 March 1981.

${ }^{62}$ TNA AT 88/132, Ministers' meeting with Broackes, Mellish and Ward, minutes, 17 November 1981, Heseltine to Broackes, 30 October 1981.

${ }^{63}$ Interview with former LDDC chief development planner, 10 September 2009.

${ }^{64}$ LDDC, Report and Accounts for 1981-82, 8.

${ }^{65}$ Hall, "Aims and Methods," 22.

${ }^{66}$ LDDC, Report and Accounts for 1981-82, 8.

${ }^{67}$ TNA AN 192/901, DoE memorandum, "The proposed LDDC - planning and development control," 5 February 1981. 
${ }^{68}$ TNA AT 41/322, Rendell note, 28 February 1980, McQuail to Valentine, 20 February 1980.

${ }^{69}$ Brownill, Developing, 131.

${ }^{70}$ TNA AT 88/111, Department of the Environment Press Notice No. 390, 14 September 1979.

${ }^{71}$ Thornley, Planning Under Thatcherism, 173.

${ }^{72}$ Newham Docklands Forum, People's Plan.

73 Hargreaves, "State Aid Continues."

${ }^{74}$ Schubert, "Waterfront Revitalisation."

${ }^{75}$ TNA AT 41/323, Note of Meeting at Thomas More St., “UDC/PLA land transfers," 27 June 1980.

${ }^{76}$ ibid., Note of meeting, 28 May 1980.

77 ibid., Note of Meeting at Thomas More St., "UDC/PLA land transfers," 27 June 1980.

${ }^{78}$ TNA 41/323, Heseltine to Fowler, 12 August 1980.

${ }^{79}$ TNA AN 81/215, LDDC Corporate Plan, October 1982.

${ }^{80}$ LDDC, Starting From Scratch, 23.

${ }^{81}$ House of Commons, Employment Effect.

${ }^{82}$ Florio and Brownill, "Whatever Happened".

${ }^{83}$ DJC, Setting the Scene, 17 and table 8, 21.

${ }^{84}$ DJC, Consultation, 10.

${ }^{85}$ TNA HLG 41/134/2, MPs' meeting with Secretary of State, minutes, 16 April 1973.

${ }^{86}$ TNA HLG 41/134/2, DoE memorandum, "Principal aspects of the report," March 1973.

${ }^{87}$ DJC, Strategic Plan, 19.

${ }^{88}$ TNA HLG 118/1773, Gunn to Richardson, 14 September 1976.

${ }^{89}$ TNA AT 88/12, DJC memorandum, "Docklands housing density," 1 March 1977.

${ }^{90}$ DJC, Consultation, 18, 58-60.

${ }^{91}$ DJC, Operational Programme, 16.

${ }^{92}$ TNA HLG 118/2084, Croft to Girling, and enclos., 2 April 1976.

${ }^{93}$ TNA AT 88/111, Department of the Environment memorandum for LDDC, “Housing policy guidelines," 14 July 1981, Rendell to Ward, 24 July 1981.

${ }^{94}$ TNA AT 81/226, Rendell to Stanley, and enclos., 22 July 1981. 
${ }^{95}$ Colenuttt and Lowe, “Does London Need,” 235-38.

${ }^{96}$ LDDC, Housing, 25.

${ }^{97}$ Brownill, Developing London's Docklands.

${ }^{98}$ Marris, Meaning and Action, 89.

${ }^{99}$ Foster, Docklands, $317 \mathrm{f}$.

${ }^{100}$ Burton, “Planning Theory," 226-30, 293.

${ }^{101}$ LDDC, New Jobs and Opportunities, 7.

102 This point about new fusions of social class and self-perception is made by Butler, "Gentrification", esp. 773-6.

${ }^{103}$ The continuing regeneration of Docklands is covered in more detail in Brownill, London Docklands Revisited and Brownill, "Just Add Water".

${ }^{104}$ GLA The London Plan.

${ }^{105}$ Raco “Local Economy” 141-53.

${ }^{106}$ https://www.gov.uk/government/news/first-4-new-generation-enterprise-zone-locations-identified, accessed 16 July 2014.

107 See http://www.neweconomics.org/blog/entry/an-alternative-vision-for-the-royal-docks, accessed 16 July 2014.

${ }^{108}$ Interview with former LDDC and London Thames Gateway UDC Board Member, 4 June 2009. 